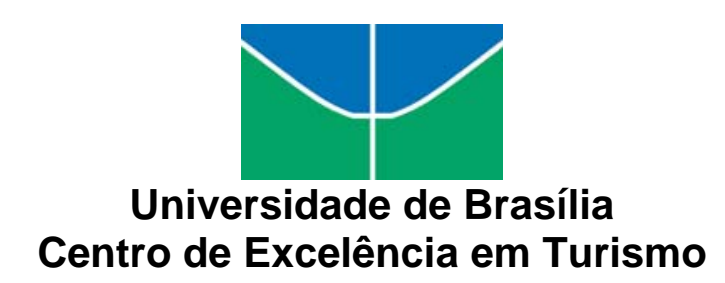

\title{
BUFÕES E CÔMICOS POPULARES: A IMPORTÂNCIA DO RISO EM SOCIEDADES PÓS-MODERNAS
}

\author{
ALEXANDRE ROCHA COSTA \\ ORIENTADOR: PROF. MARCELO DE BRITO \\ Monografia apresentada ao Centro de Excelência \\ em Turismo da Universidade de Brasília como \\ requisito parcial para a obtenção do certificado de \\ Especialista em Turismo, Cultura e Lazer.
}

Brasília - DF, junho de 2005 


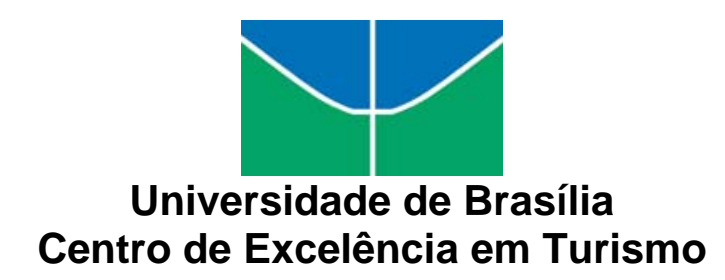

Curso de Especialização em Turismo: Cultura e Lazer

BUFÕES E CÔMICOS POPULARES: A IMPORTÂNCIA DO RISO EM SOCIEDADES PÓS-MODERNAS

\section{ALEXANDRE ROCHA COSTA}

Banca Examinadora:

Professor e Mestre: MARCELO DE BRITO (Orientador)

Professora Doutora: DULCE SUASSUMA (Membro da banca)

Brasília-DF, junho de 2005 


\section{DEDICATÓRIA}

Dedico esta monografia a meu pai, Roberto Benício Costa, in memorian, a minha querida mãe, Lígia Maria Rocha Costa, as minhas filhas, Alycia Victória e Júlia, e às pessoas que acreditam no valor da cultura popular e do riso cômico. 


\section{AGRADECIMENTOS}

Agradeço à Dona Lígia, à Isabella, a meus guias e mentores, a meu Bufão.

Agradeço ao orientador Marcelo de Brito (Kapish) por me mostrar os caminhos da construção desta monografia.

Agradeço a todos que contribuíram com apoio e incentivo para o término deste trabalho de pesquisa.

E a todos meu muito obrigado. 
Quando os Deuses se encontraram e riram pela primeira vez, eles criaram os planetas, as águas, o dia e a noite.

Quando riram pela segunda vez, criaram as plantas, os bichos e os homens.

Quando gargalharam pela última vez, eles criaram a alma. 


\section{RESUMO}

O trabalho enfoca a relação entre os bufões medievais, personagens e cômicos populares, tendo a criação e a produção do riso como fator integrador em atividades do teatro, do turismo e do lazer. A cultura popular, o teatro popular, os cômicos, os bufões, os palhaços, os clowns e os brincantes são exemplos do exercício do riso, visando especialmente demonstrar a importância de artistas cômicos, na historiografia e nas programações de lazer e entretenimento, como estratégia da ocupação da rede hoteleira, espaços de lazer e parques temáticos, bem como os espaços específicos para cultura e lazer no DF.

O riso apresenta grande capacidade reintegradora de elementos da cultura, proporcionando qualidade de vida, bem-estar, ao mesmo tempo em que desenvolve as potencialidades lúdicas dos indivíduos em sociedades pós-modernas.

Palavras chaves: Bufões - Cultura popular - Riso. 


\begin{abstract}
This paper focuses on the connection between medieval jesters, popular comics and characters, viewing laughter as and integrating factor in theatrical entertainment for tourists. Popular culture, theater, comics, jesters, clowns and fools are examples of the exercise of laughter and provoking laughter. We especially aim at demonstrating the relevance of comics in the historiography and in leisure and entertainment public programs, as a strategy in the growth of the occupancy rates in hotels, of the number of public leisure facilities, particularly those geared towards culture. Laughter has a great capacity for reintegrating elements of culture, bringing forth higher quality of living, well-being while developing the ability for having fun in individuals in the postmodern society.
\end{abstract}

Key words: jester, popular culture, laughter. 


\section{SUMÁRIO}

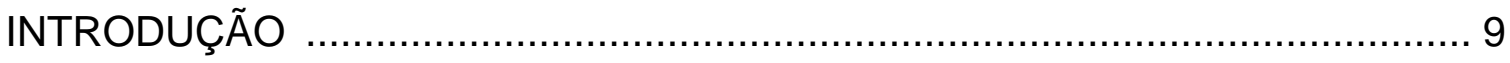

CAPÍTULO I - QUADRO CONCEITUAL .................................................. 11

1.1. Turismo e suas definições ................................................................. 11

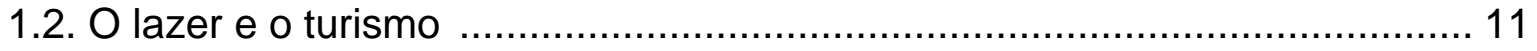

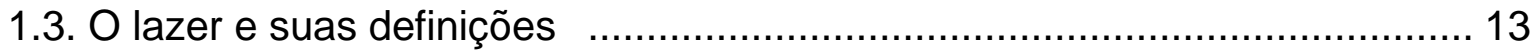

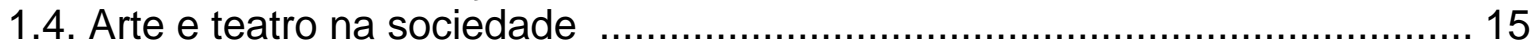

1.5. Cultura popular/ comédia popular ....................................................... 16

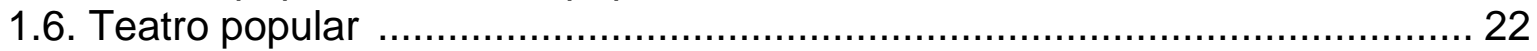

1.7. Contexto onde trafegam a arte, o turismo e a cultura popular ...................... 24

CAPÍTULO II - A TRAJETÓRIA DOS CÔMICOS POPULARES ....................... 31

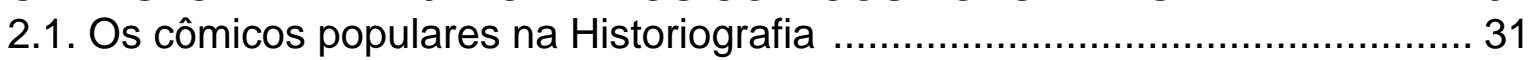

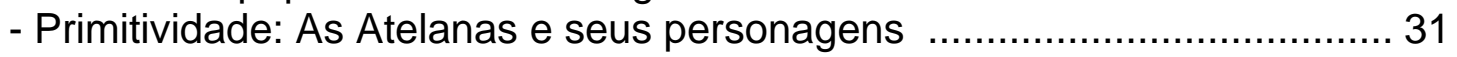

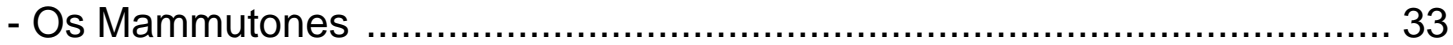

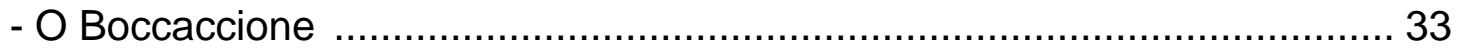

- O bufão e os bobos da idade média ....................................................... 34

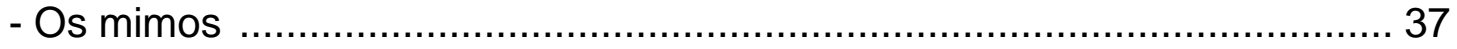

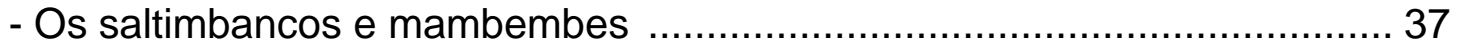

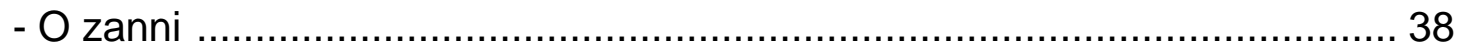

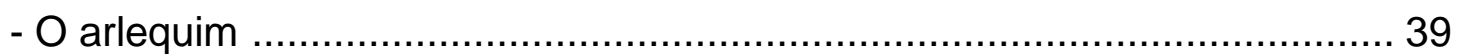

- O pierrot: a comicidade ingênua francesa ............................................. 40

- O palhaço o riso personificado - Século XVII e XIX ............................... 40

- O clown: o remédio da sociedade pós-moderna ..................................... 43

- A commédia dell'arte e a improvisação ................................................... 46

- A presença de um teatro cômico popular no DF: Histórias, atualidades, tendências e sua ação no turismo ......................................52

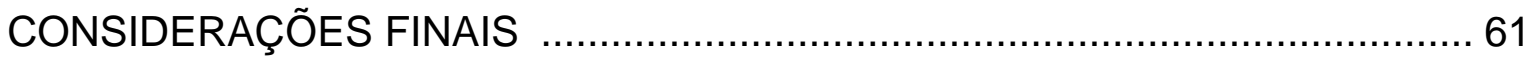

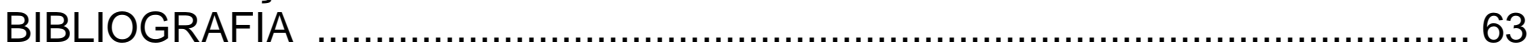

\section{A NEX O:}

A RECREAÇÃO E A ANIMAÇÃO TEATRAL: CONCEITOS E MERCADO

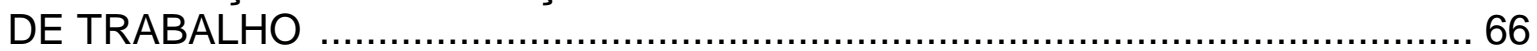

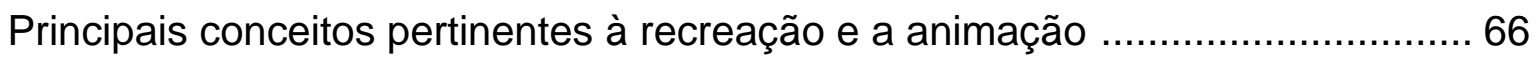

O mercado atual dos animadores cômicos populares .................................... 80

Os profissionais e principais áreas de atuação ........................................... 80 
Costa, Alexandre Rocha.

Os bufões e os cômicos populares: a importância do riso em sociedades pós-modernas.

$\mathrm{N}^{0}$ de folhas: 81.

Monografia do Curso de Especialista em Turismo: Cultura e Lazer, Universidde de Brasília, Centro de Excelência em Turismo (CET).

Orientador: Marcelo de Brito

1. Bufões. 2. Intervenções lúdicas. 3. Animação teatral. 


\section{INTRODUÇÃO}

A presença de personagens como bufões, bobos, palhaços, brincantes entre outros, presentes no teatro popular de Shakespeare, Cervantes; os tipos cômicos da commedia dell'arte, em Mòliere, permitem, através da personificação do ser cômico, uma leitura de caracteres e práticas sociais. A personagem cômica é elaborada também de ambigüidades; os seres cômicos personificam um outro ser, sendo o outro lado de uma máscara do riso, nesta sociedade de seres pós-modernos.

Tendo por base a leitura de autores que tomam o riso como objeto de investigação, tais como Dario Fo, Eugênio Barba, Stanislavski, Rabelais, Shakespeare, Cervantes, Bakhtin, Bergson, De Masi, Dumazedier, Molière, observase que o sujeito pós-moderno vem perdendo o contato efetivo com o riso, gerando um abalo na expressão das emoções e afetos desse mesmo sujeito. A arte e o turismo discutem a inserção do riso nas atividades sociais que envolvem o lazer e o entretenimento, promovendo subjetividades em estruturas pós-modernas.

A crítica atual demonstra que os personagens cômicos, ao longo do tempo, vêm sobrevivendo em face às transformações tecnológicas que recaem sobre o sujeito. Por outro lado, as atividades teatrais, lúdicas, culturais sustentadas por personagens cômicas atualizam-se à medida que se integram a novos espaços urbanos junto a serviços de lazer.

Lazer e recreação são meios práticos extensivos à expressão cultural do riso que se realiza por via de atividades turísticas receptivas, em parques temáticos e espaços para atividades lúdicas diversas. Geralmente, em tais atividades, ressaltase a importância dos bufões e cômicos populares na geração e intensificação de fluxos turísticos em sociedades pós-modernas.

Enfocando tais relações entre cultura popular, entretenimento e teatro, na promoção do riso, o objetivo geral desta pesquisa discute, do ponto de vista teórico, a relação entre bufões, riso, lazer e cultura popular no cenário do turismo, a partir de atividades lúdicas. Nos objetivos específicos, a pesquisa aborda a investigação histórica da trajetória dos cômicos populares, ressaltando o papel dos bufões e do riso na pós-modernidade, pautada no contexto cultural de Brasília. 
A apresentação deste trabalho se faz de forma sistêmica, discorrendo o Capítulo I sobre questões conceituais como: o que é turismo, o lazer e o turismo, o lazer e suas definições, a arte e o teatro, cultura popular e outros.

No Capítulo II, apresentou-se a trajetória historiográfica dos cômicos e personagens populares que se utilizavam do riso como fator de cura social.

O Capítulo III responde a considerações do processo investigatório teórico e arrisca-se a algumas conclusões acerca da relação entre o riso e bem-estar. 


\section{CAPÍTULO I}

\section{QUADRO CONCEITUAL}

\subsection{Turismo e suas definições}

Etimologicamente o vocábulo "turismo" surge na Inglaterra do século XVIII, embora sendo derivado da palavra tour, de origem francesa, esclarece BARRETTO (1991, p.43). Na literatura específica, encontramos várias definições sobre o turismo que vale a pena destacar. Uma das mais recentes definições de turismo é a do mexicano OSCAR DE LA TORRE:

"O turismo é um fenômeno social que consiste no deslocamento voluntário e temporário de indivíduos ou grupos de pessoas, que fundamentalmente, por motivos de recreação, descanso, cultura ou saúde, saem do seu local de residência habitual para outro, no qual não exercem nenhuma atividade lucrativa, nem remunerada, gerando múltiplas inter-relações de importância social, econômica e cultural." (LA TORRE, 1992, p. 19).

Depois de todas estas definições, podemos constatar que valores e características da sociedade emergente e pós-moderna está fundamentada no tempo livre, no lazer e no ócio, favorecendo ao indivíduo, à ciência, à arte e à qualidade de vida.

A pós-modernidade se refere a uma nova época, uma nova ordem sóicoeconômica, associada a noção de pós-cultura, ao crescimento do setor de serviços (urbanização, tecnologia, modernização), ao entretenimento em parques temáticos e profissionais (animadores) recreadores voltados para práticas hedonisticas, complexas por atrações repulsões, emoções, paixões, pelo prazer e pelo trabalho de forma lúdica.

\subsection{O lazer e o turismo}

Quanto aos fatores sócio-culturais, na década de $70 \mathrm{com}$ a sociedade estruturada de acordo com o processo produtivo (o mesmo que baniu à arte do 
cotidiano do trabalhador). Foi identificado o potencial dos fatores artísticos para 0 incremento do turismo. Com a possibilidade dos atrativos artísticos e recreativos envolverem turistas de todos os segmentos sociais, etários e intelectuais. Fauster, detectou dentro das correntes turísticas três grupos distintos em relação à arte: Um grupo que é indiferente à arte e corresponde à minoria e um grupo que é representado pela maioria da massa de turistas, que foi identificado como consumidores em potencial dos atrativos turísticos e recreativos que poderia ser o público alvo das estratégias de marketing (Fuster, 1974).

Os valores emergentes desta sociedade pós-industrial, privilegiam o turismo cultural (é aquele que se pratica para satisfazer o desejo das emoções artísticas e informação cultural, visando momentos históricos, obras de arte, relíquias, antiguidades, concertos de música, museus, pinacotecas, teatros e outros.

Valores como a intelectualidade, subjetividade, hospitalidade feminilização, desestruturação do tempo e do espaço, criatividade, qualidade de vida e emotividade, criam a ambientação que favorece "a estética, a arte e o turismo".

Dentre estes valores, destaca-se o tempo livre - em função da maior duração da vida e do menor tempo de trabalho - como o que mais favorece as atividades artísticas, lúdicas e recreativas. Segundo a teoria do "Ócio Criativo" de Domenico De Masi, o homem atual tende a ocupar este tempo com atividades criativas, prazerosas e que favoreçam a contemplação. Vale dizer que esse tempo pode ser ocupado com atividades artísticas, recreativas, tanto do ponto de vista do "fazer" quanto ao "apreciar". Em razão disto pode ganhar força o turismo que possibilita a fruição da estética e da arte.

Quanto aos lugares favoráveis ao turismo no mundo, a implementação da filosofia do "ócio criativo" de Masi indica o Brasil, ao lado da Itália, da Espanha e da Índia justificando as escolhas pelas paisagens, clima, obras de arte, tradição religiosa, cultura com a inclinação à poesia, ao repouso, a introspecção, à alegria, e ao convívio (De Masi, 2000). Esta lista de motivos evidencia o valor do patrimônio cultural e artístico como recurso para a nova vigência que se instala. 


\subsection{O Lazer e suas definições}

O termo lazer vem do latim "licere", que significa "ser permitido", ou seja, significa poder executar livremente tarefas não obrigatórias. A idéia de lazer remete positivamente à noção do ócio.

No lazer, o homem também procura ampliar os contatos sociais e alargar o horizonte intelectual, com vivências inovadoras, em áreas diferentes da profissional e das tarefas obrigatórias, que agem como terapia do equilíbrio físico e emocional. O lazer atua como elemento integrador do indivíduo no mundo conflituoso em que precisa viver. Como lembra Dumaze Dier, este movimento gerou, sobretudo no início do século $X X$, inquietudes.

Dumazier, atribui a utilização do tempo livre tanto para o engrandecimento, tanto para a degradação dos homens tanto assim este autor enfatiza a condição de liberdade de escolha como inerente ao lazer. Para Coriolano em lazer e turismo em busca de uma sociedade sustentável (...) o turismo é uma forma estilizada de lazer. E uma modalidade de tempo livre e o uso de um equipamento por mínimo que seja com transportes e hotéis. As atividades de lazer são em princípio higênicas, salutares. O ócio vai sendo cada vez mais associado à preguiça, a imoralidade, à improdutividade, ao vício.

A ludicidade deve trabalhar com a intenção de estimular a prática do lazer ativo, a ação e a integração do indivíduo com o meio e com os outros.

"A invenção do relógio mecânico e sua difusão, concorreram para a separação do tempo e espaço, criando um tempo vazio qualificado e dividido (GIDDENS, 1991, p. 26).

O lazer como qualidade da experiência de prazer vivida pelo homem nasce com a cidade e a indústria. O lazer definido por MARCELLINO $(1987$, p. 31) é:

"A cultura compreendida no sentido mais amplo - vivência (praticada e fruída) no 'tempo disponível' das pessoas, ocorre no âmbito de um universo de conhecida referência do indivíduo, do qual ele extrai as opções e os meios para sua reabilitação; com determinados valores como a livre adesão, que possibilite condições de descanso, divertimento, desenvolvimento pessoal e social" (Marcellino, apud Departamento de Lazer, 1997). 
O lazer, diante das características de interação, integração e participação configura-se em instrumento privilegiado de ação interdisciplinar que contribui sensivelmente na qualidade de ação de vida da população.

Acredita-se que uma compreensão adequada de lazer deve encará-lo como:

"Conjunto de ocupações as quais o indivíduo pode entregar-se de livre vontade, seja para repousar-se, seja para divertir-se, recrear-se e entreterse, ou, ainda para desenvolver sua informação ou formação desinteressada, sua participação social voluntária ou sua capacidade criadora. Após livrar-se ou desembaraçar-se das obrigações profissionais, familiares ou sociais". (JAMESON, 1984).

$\mathrm{Na}$ atualidade, este pensamento sempre vem imbuído ou agregado aos valores, muitas vezes, muitos indivíduos não tem condições financeiras para desfrutar tais atividades (cinema, teatro, ópera, galerias). Mas a televisão realiza o papel de várias formas de lazer, servindo ao consumidor, na hora que ele quer, realizando ou não suas tarefas no tempo do ócio ou não.

Para Dramante, o lazer se expressa da seguinte forma:

"O lazer se traduz por uma dimensão privilegiada da expressão humana dentro de um tempo conquistado, materializada através de uma experiência pessoal criativa, de prazer e que não se repete no tempo/espaço, cujo eixo principal é a ludicidade. Ela é enriquecida pelo seu potencial socializador e determinada, predominantemente, por uma grande motivação intrínseca e realizada dentro de um contexto marcado pela percepção de liberdade. É feita por amor, pode transcender a existência e, muitas vezes, chega a aproximar-se a um ato de fé. Sua vivência está relacionada diretamente às oportunidades de acesso aos bens culturais, os quais são determinados, via de regra, por fatores sócio-político-econômico e influenciados por fatores ambientais." Bramante, Antônio (1998).

Pensando e refletindo com esta definição de Bramante, coloco em questão para se pensar, a hipótese do porquê do não desenvolvimento do DF, como pólo de culturas e lazeres nacionais, pois, a cidade sendo a capital do país, deveria agregar e desenvolver as mais diversas formas de expressões culturais do Brasil, mostrando para todos os visitantes e turistas a importância de se divulgar as várias culturas existentes no país. 


\subsection{A arte e o teatro na sociedade}

A arte e o teatro sempre fizeram parte da sociedade e da evolução humana. Apesar da sociedade atual, por força de suas características, direcionar o homem não só para atividades criativas, pode-se perceber pelo seu histórico que a arte e o teatro são inerentes ao homem, estando sempre presentes na sua vida.

A realidade circundante ao homem se constitui na convivência com a natureza, com os outros homens e com sigo mesmo. Para se beneficiar das dádivas da natureza e não sucumbir às suas intempéries o homem precisou dominá-la, transformá-la. Contou com o apoio e a cooperação dos demais companheiros de tribo para sair vitorioso na luta pela sobrevivência. Para ajudar o enfrentamento, foram inventados instrumentos cuja resistência superasse as forças do corpo humano. De tudo esse esforço resultou a socialização, o trabalho, o desenvolvimento tecnológico e a arte (Aranha, 1993).

Da necessidade de comunicação surgiu a linguagem, que serve para repassar as mensagens sobre as experiências vividas e a interpretação pessoal acerca das impressões recebidas. Ao eleger as linguagens, o homem expressa conceitos oriundos da razão e comunica experiências que precedem da emoção acrescidas das informações percebidas sensivelmente pela intuição (ID. IBID).

O que para expressar o sentimento a respeito das experiências vividas, o homem o faz através da arte, ou seja, das linguagens artísticas (sonoras, cinestésica, gestual, plástica, visual). Percebidas pelos cinco sentidos (audição, tato, visão, olfato, e paladar). Estas linguagens constituem as manifestações artísticas como: música, dança, teatro e as artes visuais.

O teatro, seus personagens e tipos (objetos de estudo deste trabalho), se estruturaram a partir de textos, figurinos, cenários, técnicas corporais, vozes, para criar imagens (reais ou imaginárias) que expressam os sentimentos e as emoções e dão significados às expressões humanas. É portanto uma atividade humana que busca a criação, a expressão e a produção de imagens ou sentimentos que desencadeiam novos sentimentos como o prazer e o êxtase.

O caráter estético faz com que a arte seja uma experiência que reclama a contemplação, seu caráter enigmático permite a imaginação e o sonho. 
A importância da arte na sociedade moderna e pós-moderna proporciona ao homem a fruição do prazer e a qualidade de vida.

A arte é "tão fundamental, tão ligada às necessidades elementares da civilização, que a alma nacional tem de achar expressão própria nesse meio". (Read, 1992). Levando-se em conta que a "alma nacional" é o foco das correntes turísticas , então, a arte pode ser o diferencial que interessa ao turismo de qualquer localização.

\subsection{Cultura popular / comédia popular}

A cultura popular, assim como o teatro popular, os artistas populares, as festas populares e o riso popular sempre caminharam de mãos dadas para a evolução das sociedades. Absorvendo culturas e tradições diversas, civilizações, pensamentos, interesses literários, interesses folclóricos, históricos, antropológicos e a dialética das cortes e praças.

Para Raul Zumthor, a definição ampla de cultura popular é:

“[...] A idéia de 'cultura popular' é apenas uma distinção cômoda, que permite o enquadramento dos fatos; ela se refere a usos, não a uma essência; a popularidade de uma característica de costume ou de um discurso não é outra coisa que a sua relação histórica hic et nunc com outras características, outros recursos. [...].

[...] Aquilo que, com efeito, designa a palavra culto, é uma tendência, no âmbito da cultura comum, à satisfação de necessidades isoladas da globalidade do vivido: Ao instaurar-se de comportamentos autônomos, exprimíveis em linguagens consciente destes fins de ?? nos seus confrontos; popular, a tendência de um alto grau de funcionalidade das formas, em relação a usos ligados à experiência cotidiana, a finalidades coletivas e a uma linguagem relativamente estereotipada.

Para Ítalo Calvino entendo que o sonho coletivo é o grande ensinamento da tradição da cultura popular e universal, sendo a memória coletiva sua grande expressão.

"Quem sabe o quanto é raro na poesia popular (e não popular) construir um sonho sem refugiar-se na evasão... A inversão de um destino, esta força da realidade que inteiramente explode em fantasia.

A cultura popular na Idade Média e no renascimento, é vista no contexto de Rabelais, considerado um dos grandes autores europeus do século XVI, apresenta sua força de idéias e arte, historicamente, ao lado de Shakespeare (eminente gênio da humanidade de todos os tempos e povos). 
"Rabelais recolheu sabedoria na corrente popular dos antigos dialetos, dos refrões, dos provérbios, das falhas dos estudantes, na boca dos simples e dos loucos". (Bakhtin).

Para o russo Mikhail Bakhtin (1895-1975) um dos maiores teóricos da literatura contemporânea, escreveu em seu livro, A cultura popular na Idade Média e no Renascimento, sobre o contexto de François Rabelais:

“... suas imagens estão perfeitamente posicionadas dentro da
evolução milenar da cultura popular, apresentando, uma investigação
profunda dos domínios da literatura cômica popular, iluminismo, e a
cultura popular cômica de vários milênios na qual foi eminentemente
porta-voz. Assim Rabelais, deve ser a chave dos esplêndidos
santuários da obra cômica popular".

O comportamento das pessoas, as emoções humanas, observadas em diferentes meios sociais, tendo as feiras populares (tradicionais manifestações culturais populares, carnaval, folclore, teatro), são vastas enquanto cenário de fantasia, que espontaneamente exageram o real visto nas ruas, nas praças ou nos mercados, estes rituais são a essência cultural de um povo, de uma comunidade. Dentro de suas diversidades, essas formas e manifestações (festas públicas carnavalescas, ritos, cultos cômicos especiais, os bufões, os tolos, anões, monstros, palhaços de diversos estilos e categorias, literatura paródica) possuem uma unidade de estilo e constituem partes e parcelas da cultura cômica popular, principalmente da cultura carnalavesca, fantasiosa e festiva.

Entre as numerosas investigações científicas consagradas aos ritos, mitos e às obras populares líricas e épicas, o riso ocupa apenas um lugar transitório, pois, se formaram sob o domínio da cultura e da estética burguesa dos tempos modernos, já que a burguesia e o clero nos séculos $X V, X V I$ se aproximaram das emoções lúdicas das feiras livres e dos artistas de rua. O problema da cultura cômica popular na Idade Média e no Renascimento, era encontrar o discernimento em suas dimensões e definir previamente suas características originais.

Como já observamos, o riso popular e suas formas constituem o campo menos estudado da criação popular. Seu caráter popular e folclórico (época préromântica) exclui quase totalmente a cultura específica da praça pública e também o humor popular em toda a riqueza das suas manifestações (ponto de vista cultural, histórico, folclórico, literário), isso nos permite afirmar, sem exageros, que a profunda 
originalidade da antiga cultura cômica popular, não foi ainda revelada na amplitude e importância da Idade Média e no renascimento. O mundo infinito das formas e manifestações do riso opunha-se a cultura oficial, ao tom sério, religioso e feudal da época. Para Bérgson (1899):

"O riso é a anestesia do coração e a personificação das emoções sábias, para ele o cômico pode ser descrito como fenômeno antropológico, o gosto do homem pela brincadeira, a sua capacidade de perceber aspectos insólitos e ridículos da sociedade humana (social e física)".

O cômico popular é uma arma social, que fornece ao gênero irônico, e ao riso, condições para criticar seu meio, massagear sua oposição por um traço espirituoso ou de farsa grotesca.

Fenômenos cômicos como: paródia, ironia, sátira, humor, exercidos e criados por personagens cômicos, seres cômicos, pessoas comuns, segundo Freud (1969, volume 4, pg. 188): "Quando ao se rir do outro, sempre se ri um pouco de si mesmo, esta é uma maneira de se convalescer melhor "(FREUD, 1969:188).

O riso é comunicativo, quem ri necessita pelo menos um parceiro para associar-se a ele e rir do que é mostrado, estabelecendo-se como um fenômeno social.

Segundo Mikhail Bakhtin, os artistas populares e os cômicos (bufões e bufos) desta época, utilizavam-se de códigos e gestos corporais, que facilitavam uma maior comicidade popular (através de experiências populares dos espectadores, oralidades, festas populares, circo, palhaçada) (Clownaria), na realidade o mundo cômico se dividia em 3 grandes categorias:

1) Formas de ritos e espetáculos (manifestos em):

(Festejos carnavalescos - obras cômicas apresentadas em praça pública).

2) Obras cômicas verbais (paródias).

Diversas naturezas, orais e escritas.

3) Diversas formas e gêneros do vocabulário familiar e grotescos Insultos.

Juramentos populares.

Na tese de FERRACINI (1997:125):

“... todas as formas e símbolos de linguagens carnavalescas estão impregnadas do lirismo da alternância e da renovação, da consciência da alegre relatividade das verdades e autoridades no 
poder. Ela caracteriza-se, principalmente, pela lógica original das coisas, 'ao avesso, ao contrário'..."

“... A segunda vida, o segundo mundo da cultura popular, constrói-se de certa foram como paródia da vida, ordinária como um mundo ao revés" (...) (FERRACINI $(1997,125)$.

Para Patrice Pavis, em seu dicionário de teatro, (p. 58), o cômico é:

"O cômico não se limita ao gênero da comédia, responde ao instituto do jogo, ao gosto do homem pela brincadeira e pelo riso, à sua capacidade de perceber aspectos insólitos e ridículos na realidade física e social. A arma social, fornece ao irônico, condições para criticar seu meio, mascarar sua oposição, por um traço espirituoso ou de farsa grotesca. Centra a ação em conflitos e peripécias que demonstram a inventabilidade e o otimismo humanos perante a adversidade."

Podemos, então, afirmar que o cômico possui qualidades e diferenças entre o riso popular e o riso puramente satírico:

"Uma qualidade importante do riso na festa popular é que escarnece
dos próprios burladores. O povo não se exclui no mundo em
evolução. Também ele se sente incompleto: também ele se renasce
e se renova com a morte. Essa é uma das diferenças essenciais que
separam o riso festivo do riso puramente satírico da época moderna.
O autor satírico que apenas entrega o humor negativo, coloca-se fora
do objeto aludido e opõe-se a ele (...) Ao contrário o riso popular
ambivalente expressa uma opinião sobre o mundo em plena
evolução no qual estão incluídos os que riem".

Os festejos carnavalescos, ou simplesmente o carnaval, era muito importante na vida do homem medieval, continham em seus ritos, atos cômicos, dançados e cantados, festas dos tolos, festas dos asnos, riso pascal, festas religiosas de aspectos cômicos populares. Os desfiles de cortejos com personagens e seres (bufões, bobos, gigantes, anões, animais) com origem nas Saturnais Romanas (pequenos cortejos cênicos, com muita dança e diversão) que baseavamse na vida cotidiana, caráter concreto e sensível, elemento de jogo, estavam relacionadas às formas artísticas e animadas por imagens, ou seja, as formas do espetáculo teatral.

É verdade que as formas do espetáculo teatral na Idade Média se aproximam na essência dos carnavais populares, mas os espectadores não assistem o carnaval, eles o vivem. O carnaval existe para o povo, não é teatro e sim uma forma concreta da própria vida. 
Durante o carnaval é a própria vida que é vivida e representada por um certo tempo o jogo se transforma em vida real, esta é a natureza específica do carnaval, no seu modo particular de existência, baseada no princípio do riso, e a sua vida festiva. A festa é a prioridade fundamental de todas as formas de ritos e espetáculos cômicos da Idade Média. As festividades são uma forma primordial, marcante da civilização humana.

Os bufões e os bobos são as personagens características da cultura cômica da Idade Média. De certo modo, os veículos permanentes e consagrados do princípio carnavalesco na vida cotidiana (aquela que se desenrola fora do carnaval).

Os bufões e os bobos, como por exemplo o bobo Tribolet (que atuava na Corte de Francisco I), não eram atores que desempenhavam papéis no palco, (a semelhança dos comediantes que mais tarde interpretariam arlequins, Hans Wurts, etc.). Pelo contrário eles continuavam sendo bufões e bobos em todas as circunstâncias da vida. Como tais, encarnavam uma forma especial de vida, ao mesmo tempo real e ideal. Situavam-se na fronteira entre a vida e a morte (numa esfera intermediária); nem personagens excêntricos ou estúpidos nem atores cômicos. Os bufões, colocam em evidência a existência de "regras de desordem", cujo o funcionamento permite controlar mais facilmente as oscilações entre a desordem e a ordem, a consciência de status e o jogo da fantasia e do desejo, o controle e o descontrole emocionais, o cálculo instrumental e o hedonismo, ensinando-nos a rir de nossas misérias ao invés de reprimi-las, assim como no carnaval.

As apresentações com caráter folclórico de tais personagens cômicas, desenvolvem-se em clima de festa, bem como o carnaval, por seus valores profanos e sagrados, viabilizando as festividades carnavalescas.

O carnaval é a segunda vida do povo, paródia da vida ordinária, o indivíduo feudal, parecia estar imbuído de uma segunda vida, que Ihe permitia estabelecer relações novas, verdadeiramente humanas, com seus semelhantes. A alienação desaparecia provisoriamente, o homem tornava a si mesmo e sentia-se um ser humano entre seus semelhantes, experimentava-se concretamente o fruto da imaginação ou do pensamento abstrato, contato vivo, material e sensível, eliminando as relações hierárquicas, criando linguagens na praça pública, inconcebível em situações normais. 
Entre estes dois tipos de pensamentos, como a evolução estava latente neste período histórico, sentiu-se a necessidade de substituir indivíduos, por atores que interpretavam textos. Estes atores se encontravam no teatro.

O teatro se dividia entre popular e erudito e criou-se um paralelismo entre a forma escrita e a forma improvisada, onde Ruggero Jacobi em um de seus textos (1956:22) retrata de tal forma este paralelo:

"O dualismo entre teatro literário e o teatro popular ressurge na forma
mais rígida. Os dois teatros desenvolvem-se independentemente um
do outro, no mais geométrico paralelismo: Eles se desconhecem. E a
diferença básica já começa a ser esta: O teatro das cortes é escrito,
forma-se imediatamente sobre os modelos gregos e latinos, e não
consegue alcançar resultados propriamente teatrais. teatro do povo
é improvisado, leva quase dois séculos antes de se formar
definitivamente não tem quase modelos e alcança resultados
exclusivamente teatrais" (Jaccobi, 1956: 22).

Antes de definir o teatro popular, gostaria de traçar o perfil da comédia popular e seus personagens cômicos.

A comédia popular. Originária dos arredores de Nápoles, breve a attelane se aclimatou em Roma. O começo foi uma espécie de improviso feito por amadores, conservando os profissionais, que a seguir a cultivavam, a honra extraordinária de manter, sob a máscara de ator, a dignidade de cidadão.

A attlelane representava-se, pelo menos no começo, sobre um simples estrado, encarnando os atores tipos tradicionais e de todo o sempre repetidos. Tais personagens chamavam-se Maccus, figura pesada, com uma tríplice marreca, voraz, lascivo e risível; Bucco, tipo parasitário, lambão e mentiroso; Pappus, velho rabugento, sempre correndo em perseguição de mulheres ou agarrado ao pé-demeia, e Dossennus, também marreca, pedante e aldeão, caricatura do adivinho. Em torno destas figuras outras se moviam, fazendo parte da sua família, os criados (Sannion), além de Manducus o Papão, do lobisomem Lamia; e das Manies, fantasmas que muito assustavam as crianças.

A atellane era uma farsa grandemente apimentada; qüiproquós, complicações, pancadaria, desordens e disparates diversos compunham o tempero que, por vezes, uma pontinha de sátira política vinha animar. No tempo de Cícero já passara a grande voga desta comédia. No entanto, os imperadores ainda verão com desagrado o mínimo de liberdade política que isso representava. 
O mimo, produto mais deturpado de proveniência greco-asiática, era um misto do nosso "music-hall" atual e do antigo "vaudeville", criando-se, durante o império, uma espécie de grande espetáculo, análogo às revistas atuais de grande montagem.

A pantomima uma espécie de improvisação codificada que se alimenta de estímulos que vem de seus espectadores começou, então, a fazer furor. Era uma espécie de tragédia lírica, reduzida a um solo mimado, acompanhado pelo coro e por diversos instrumentos. O ator encarnava, sob várias máscaras, diferentes personagens. E a arte de tais atores, efeminada como eles próprios, era exímia na maneira de figurar as paixões voluptuosas.

Sucessivamente, os filósofos pagãos e os doutores da Igreja protestaram violentamente contra tais exibições. Nada conseguiram, no entanto, pois tinham-se tornado indispensáveis ao povo que se habituara a reclamar o circo ao mesmo tempo que pedia pão. Faziam-se apostas nas corridas de cavalos, nos pugilatos, nos combates de gladiadores, nas batalhas navais em miniatura, realizadas dentro dos anfiteatros em todos os festejos, e onde, quase sempre, sangue humano era derramado, tornando-se isso numa espécie de droga cuja dose se tornava indispensável aumentar em virtude da habituação. Tais espetáculos haviam começado, em fins da República, com verdadeiros deboches de "mise-en-scénes": depressa, porém, o povo exigiu que sangue verdadeiro corresse e mortes autênticas se dessem. E tão bestial realismo destruiu por completo a virtuosa purificação que é a ficção, humilhando assim a Arte.

Com isso surge a idéia de uma arte, ou melhor, teatro popular, que será tratado a seguir.

\subsection{Teatro Popular}

1. A noção de teatro popular, invocada hoje com tanta freqüência, é uma categoria mais sociológica que estética. A sociologia da cultura define assim uma arte que se dirige e/ou provém das camadas populares. A ambigüidade está em seu auge quando nos perguntamos se se trata de um teatro originário do povo ou destinado ao povo. E, aliás, que é o povo, e, como perguntava Brecht, o povo ainda é popular? 
O mais simples, para desenrolar a meada, é determinar a que noções aquela de teatro popular se opõe, já que é verdade que o termo tem um uso polêmico e discriminatório:

- O teatro elitista, erudito, o dos doutos que ditam as regras;

- O teatro literário que se baseia num texto inalienável;

- O teatro de corte cujo repertório se dirige, no século XVII, por exemplo, aos altos funcionários, aos notáveis, às elites aristocráticas e financeiras;

- O teatro burguês (boulevard, ópera, setor de teatro privado, do melodrama e do gênero sério);

- O teatro italiano, de arquitetura hierarquizada e imutável que situa o público à distância;

- O teatro político que, mesmo sem ser vinculado a uma ideologia ou um partido, visa transmitir uma mensagem política precisa e unívoca.

Diante de todos esses duplos, o teatro popular tem muita dificuldade em encontrar sua própria identidade. Se ele sempre existiu ao lado do teatro literário (como, por exemplo, a Commedia dell'arte ao lado da commedia erudita), somente no final do século XIX ele tenta institucionalizar-se: assim a Freie Volksbühne em Berlim (1889), o Teatro do Povo de Maurice Pottecher em Bussang, o Volkstheater de Viena, os esforços de Rolland e de seu ensaio O Teatro do Povo (1903) e suas peças: Danton, lê 14 Juillet. Na França, o projeto popular ressurge após a Segunda Guerra Mundial, sob o impulso dos altos funcionários da cultura como Jeanne Laurent ou de encenadores como Jean Vilar e Roger Planchon, bem como dos teóricos reunidos em torno da revista Théâtre Populaire (1953-1964). Os criadores estão em busca de um estilo, de um público e de um repertório acessível à grande maioria. A bem da verdade, tal público popular compreende apenas poucos operários ou camponeses; ele se recruta, sobretudo, entre a pequena burguesia intelectual, executivos, professores.

Existiu um repertório popular? As peças representadas pelos aldeões, os canevas nos quais se inspiravam os artesãos da Commedia dell'arte não constituem um repertório que se conservou até nossos dias. No século $X X$, os grandes textos clássicos é que são encarregados de reunir o público, como se essas peças falassem diretamente à grande maioria; a ambigüidade é grande, pois pode-se também, com Sartre, por exemplo, ver no teatro de repertório um teatro popular tradicional e um fato cultural burguês (Sartre, 1973). 
Recentemente, o teatro popular não parece ser mais uma unanimidade entre a gente de teatro: Vitez fala de um teatro "de elite para todos" e "o público popular, é simplesmente isso: o público... em expansão - não necessariamente muito popular" (Loisir, novembro 1967, p. 17). Fala-se muito mais em teatro intercultural (Brook) ou teatro de participação (Boal), de vota às tradições teatrais (Commedia dell'arte, Nô, etc.) ou, numa outra ordem de idéias, do teatro de boulevard, de programas de televisão, como o muito "popular" Au Théâtre ce Soir, ou da cultura pop ou dos mass-media (televisão e vídeo, principalmente). Essa cultura de massa talvez tenha tornado vã qualquer esperança de favorecer a criatividade das forças populares. A popularidade não prova mais grande coisa nesses tempos da mídia.

O teatro popular contava com o improviso em suas apresentações e o improviso tem haver com a commédia dell'arte:

\subsection{Contexto onde trafegam a arte, o turismo e a cultura popular}

Com a evidência da importância do turismo para a economia, a política e a cultura, essa atividade passou a ter um espaço privilegiado em inúmeros papéis. Colabora para isso, o ritmo acelerado da sociedade atual onde surgem situações e valores que sejam as necessidades e criam as novas motivações para as viagens. Em vista desta demanda são colocados no mercado os mais variados atrativos que oferecem ao homem atual e pós-moderno a oportunidade de vivenciar o chamado "ócio criativo" e permite a prática do turismo de acordo com os princípios da sustentabilidade. os atrativos turísticos colocados no mercado são classificados em 2 grandes grupos: os atrativos naturais; os atrativos culturais ou artificiais.

No presente estudo destaca-se a arte (teatro) e a cultura popular (seus criadores e fazedores) como um dos recursos culturais geradores de fluxo turístico.

Para a sociedade atual, a conexão entre tais atividades resulta em benefícios para uma vida plena de valores equivalentes entre a natureza e o ser humano e a consciência de que ambos precisam ser valorizados, respeitados e protegidos.

"A experiência individual direta com o ambiente, a paisagem e os nativos(...) passa a ser um valor dos mais apreciados para a afirmação do individualismo contemporâneo". O sujeito "revisita" suas próprias passagens mentais, redescobrindo-as com outros significados reveladores, dessa vez 
de novas interpretações do seu lugar e dos outros no mundo" (Serrano, 1997 pg. 83).

Fuster apontou o turismo como uma atividade capaz de atender a demanda da então futura civilização do ócio, essa percepção vai se confirmando nesta sociedade, onde, segundo De Masi (2000), "a era industrial cede lugar ao tempo livre, à estética, a criatividade e a subjetividade". De Masi observa que a sociedade industrial, economicamente calcada na produção de bens e na relação capital $x$ trabalho, cede espaço para a sociedade do "ócio criativo". Para Dumazedier, em seu pressuposto de base é o debelar um projeto de democratização para aproximar a maior quantidade de pessoas da cultura, por meio do movimento "povo e cultura" e do desenvolvimento do método de animação sócio-cultural. Define então, ação sócio-cultural no lugar de cultura (DUMAZIER, 1950, 53):

"Forma consciente, intencional, organizada e mesmo planejada, de culturação, que se opõe às formas de condicionamentos cegos e anárquicos". E define cultura popular como: "conjunto dinâmico de valores, de noções e de atitudes que tendem a tornar-se uma produção comum a todas as classes sociais, e cujo efeito é favorecer à promoção cultural dos meios populares e diminuir a distância social que os separa das camadas privilegiadas".

O ócio para Dumazedier é:

"Uma escolha que deixa uma impressão de prazer no indivíduo (...) uma atividade a qual o indivíduo adere livremente de bom grado (...) (1966). Conjunto de atividades as quais o indivíduo pode se dedicar plenamente para descansar, para se divertir ou para desenvolver seu conhecimento ou sua formação desinteressadamente, sua participação social voluntária ou sua livre capacidade criadora, quando livre de obrigação profissionais, familiares e sociais (1950). Daí surgem os conhecidos 3D: descanso, divertimento, desenvolvimento (funções do ócio e do lazer). $(1950,53)$.

O ócio também pode ser considerado uma visão de vida, para aquele indivíduo que gosta do que faz, a observação do mundo a nossa volta, e a contemplação do tempo e do espaço.

Os comediantes italianos não aprendem nada com o coração, Ihes é suficiente, para interpretar uma comédia, apenas ter observado o sujeito (a personagem) um momento antes de estar em cena.

Na visão de De Masi, o ócio criativo é:

"O ócio criativo" é definido como conjunto de valores que se contrapõem ao modelo social centrado no culto ao trabalho, ao 
mercado e à competitividade. Baseia-se na simultaneidade entre trabalho, estudo e lazer, é centrado no aumento do tempo livre; à justa distribuição da riqueza; e também, privilegia a introspecção, o convívio, a amizade, o amor e as atividades lúdicas" (De Masi, 2000).

Esta sociedade base, denominada pós-industrial, tem a base econômica na produção de serviços e não na de bens; é fundada no deslocamento e na reunião de pessoas, mercadorias e informações provenientes de todas as partes do mundo; privilegia a produção de idéias; tem a responsabilidade de buscar o desenvolvimento sustentável por causa da consciência que tem do planeta, como sistema finito, contrapõe a subjetividade à massificação da sociedade industrial; promove a diminuição do trabalho aumentando o tempo livre, provoca aumento da massa das pessoas que não trabalham (estudantes, desocupados e idosos), gera desemprego em função da diminuição do trabalho de execução e do aumento do trabalho de tipo criativo. Acontecerem em ritmos diferenciados, favorece a globalização dos meios de comunicação de massa, da ciência, do dinheiro, e da cultura devido ao processo tecnológico, apresenta tendência de aumentar o tempo de vida, libera o homem para o trabalho criativo, prazeroso, deixando às máquinas o trabalho executivo; valoriza à estética que passa a ser o diferencial de um objeto tecnicamente criado em igualdade de condições com o outro; diminui pequenos deslocamentos e aumenta os grandes deslocamentos de grandes distâncias e outras cidades, países, continentes (De Masi, 2000).

As motivações individuais, ou desejos de conhecimento de si mesmo, de outro ser humano e do ambiente em que se movem os habitantes de uma localidade (Fuster, 1974) e as motivações sociais (necessidades humanas de relacionamento social, reconhecimento e estima) influenciam os fluxos turísticos que aumentam e se diversificam a cada dia. O tempo livre, na prática "significa viagem, cultura, erotismo, estética, repouso, ginástica, esporte, meditação, reflexão". (Práticas como assistir ao pôr do sol, ou o nascer da lua, caminhar observando a estética dos vegetais, e sentindo o aroma dos ambientes, são práticas que proporcionam a utilização do tempo livre de forma criativa (De Masi, 2000).

A valorização da intelectualidade também abre campo para as atividades ligadas ao turismo, a arte e a cultura popular. De Masi(2000) diz que tanto no trabalho quanto no lazer as atividades cerebrais predominam em relação as manuais, estas idéias estão de acordo com a opinião de Trigo (1996): 
"Nas sociedades pós-industriais, o turismo juntamente como o lazer, a cultura, as áreas, o esporte e a preocupação com a qualidade de vida, desenvolveu-se a cada ano, ganhando sempre mais espaço nos meios de comunicação, nos negócios internacionais, no interesse e no cotidiano das pessoas".

Este contexto favorece a expansão da arte, do turismo e da cultura popular e gera valores que podem conduzir ao turismo artístico, recreativo e teatral para detectar pontos de conexão existentes entre arte, turismo e cultura. É preciso considerar as características desta sociedade, seus valores emergentes, que ao delinearem a vida atual e futura, criam condições que impulsionam a arte, a cultura popular e o turismo conforme a indicação a seguir:

- A econômica baseada na produção de serviços, levou a indústria de viagens e turismo ao $1^{\circ}$ lugar no mundo (com projeções apontando para sua crescente consolidação nos próximos 20 anos) e ao $4^{\circ}$ lugar no Brasil. A arte, cuja sua relação com o capital surgiu no início do século $X X$, tem um crédito nestes resultados, posto que o serviço dedicado ao lazer e ao entretenimento é comum a ambas as indústrias. Em Nova York, a indústria cultural, representa a segunda fonte de divisas, e no Brasil movimenta cerca de 1\% do PIB, com oferta de empregos que ultrapassam a indústria automobilística.

- A indústria da tecnologia em todos os aspectos da vida humana vem proporcionando informações massivas e beneficia a arte, o turismo e a cultura: "Cria as motivações para viajar, assistir um filme, conhecer um lugar, sentir um determinado ambiente" (De Masi, 2000). Atuando sobre o desejo de status provoca o deslocamento para lugares exóticos, algumas vezes, menos interessantes que as imagens exibidas. Pode gerar fluxos para comprar uma mercadoria, ver um evento artístico ou buscar conhecimento.

- Já a criatividade é um fator que além de favorecer o turismo, a cultura e a arte, também se beneficia deles, a mudança de ambiente estimula a criatividade ao proporcionar o distanciamento das atividades rotineiras. A criatividade deixa de ser causa e passa a ser conseqüência das duas atividades quando elas propiciam a valorização da emoção e da família como ingredientes que se juntam à razão e a concretude no lazer humano. Por sua vez, a conquista de melhor qualidade de vida, que implica em estimular e satisfazer os sentidos buscando o prazer, a saúde física e mental, acarreta os deslocamentos para descanso, recreio, entretenimento, etc., 
ou a busca da arte (teatro) para a liberação de tensões catarse, desfrute visual, cinestésico, etc.

"O futuro pertence àqueles que serão mais capazes de usar suas próprias cabeças do que as próprias mãos" e as pessoas que se dedicarão à análise de sistemas, pesquisa científica, psicologia, marketing, relações públicas, tratamento de saúde, organização de viagens, jornalismo, e a formação isto é, à educação nesses tempos (De Masi, 2000); os que desejam crescer devem tentar tornando-se produtores de idéias, investindo na pesquisa científica, na produção artística e na formação de jovens".

Assim, como os valores que surgem impulsionam a arte, a cultura e o turismo, torna-se preciso às sociedades em fase de transição criar os mecanismos que favoreçam as conexões necessárias ao novo ritmo de vida.

A arte, a cultura popular e o turismo, são três realidades distintas que podem apresentar pontos em comum, se complementarem, ou ao contrário, podem ser atividades paralelas, sem qualquer vinculação.

A trajetória da arte com todos os seus mecanismos corresponde à própria trajetória do homem. E o turismo pode ser considerado uma atividade que permeia, junto com a cultura, duas características herdadas do homem pré-histórico que são: o sedentarismo e o nomadismo.

A arte oferece vários caminhos: do fazer, permite ao homem estabelecer uma ligação íntima com a natureza e se transformar. Do conhecer e do apreciar: a beleza e a estética funcionam de modo significativo ao sistema de valores de quem aprecia a obra já pronta, seja ela musical, teatral ou visual.

"Mas para viver o "ócio criativo" é preciso aprendizagem por parte dos jovens e reaprendizagem por parte dos adultos. Os indivíduos precisam ter à sua disposição programas ricos em atividades lúdicas e culturais para que se aprenda a viver o ócio de forma inteligente. Segundo esta teoria, o tempo livre oferece a possibilidade de introspecção, de jogo, de convívio, de amizade, de amor e de aventura que exigem aprendizado. Quer dizer que o jovem além de aprender a trabalhar, "precisa aprender a ser pai, telespectador, cidadão e turista. Desenvolver a capacidade de escolher um filme, um concerto, um balneário. Ele deve aprender a escolher e a apreciar uma boa culinária, um bom hotel, e as belezas da natureza e da arte (De Masi, 200). 
Para isto as cidades e as instituições precisam de se "adequar para uma vida coletiva na qual predomina o lazer e um número cada vez maior de atribuições que devem ser realizadas não em função de quem trabalha, mas em função de quem repousa, ou se diverte. (De Masi, 2000).

Esta repercussão e adequação pode auxiliar positivamente a arte, a cultura e o turismo. Há lugares que o teatro e a recreação são fatores fundamentais para a movimentação turística em detrimento dos espaços lúdicos. (Fuster, 2000). Em outros lugares pode assumir funções variadas, como atrativos coadjuvantes das diversas tipologias do turismo, de acordo com a relação abaixo:

1) De lazer: o contato com as atividades culturais (teatro/recreação) proporciona ao turista a possibilidade de realização prazerosa de algo que tem valor em si e não para outro fim.

2) Cívica: quando a obra teatral se converte em símbolo representativo de uma nação.

3) Ecológico: quando os personagens ou tipos se integram no conceito educativo e explicativo prescrito pela filosofia do desenvolvimento sustentável.

4) Educativo: o estudante amplia a visão de mundo no confronto com a visão do artista e desenvolve a sensibilidade e o gosto estético no contato direto com o teatro de outras localidades.

5) terapêutica: atividades artísticas e lúdicas como propostas alternativas para jovens, adultos e idosos, podem aliviar tensões, eliminar o estresse, recompor as energias, promover descanso, desenvolver a memória emotiva, etc.

6) Social: repercussão positiva do teatro no turista, ao identificar através da linguagem universal da arte, as influências de seu próprio país no local visitado.

7) Cultural: a arte local, popular ou erudita, e o que distingue um país, proporcionando ao turista o valor do novo.

8) Documentária: como registro histórico, a arte é a fonte para o turista conhecer as tradições, os hábitos, as crenças dos habitantes do local visitado.

9) Divulgação: os elementos da estética podem despertar o desejo e gerar as motivações para as viagens.

10) Lúdica: participação direta nas obras (apresentações interativas) provocando o prazer na criação de novas formas.

Em contato com eventos, o teatro e as atividades teatrais também constituem um fator de inumeráveis possibilidades para o turismo. Em princípio sem 
restrições quanto a local, devido à sua mobilidade, os eventos podem ser organizados de acordo com o critério preferido entre as várias alternativas de apresentações cênicas:

1) Quanto as combinações: cronológicas, temáticas, estilísticas, geográficas, técnicas, funcionais, de autoria.

2) Quanto aos objetivos: mercantis, do conhecimento, comemorativo, de marketing, educativos, intercâmbios, profissionais, estéticos, sócias.

3) Quanto aos tipos de eventos: exposições, salões, concursos, festivais, férias, leilões, desfiles, mostras, etc.

4) Quanto aos locais: museus, espaços urbanísticos, galerias, centros de cultura, bibliotecas, órgãos públicos, empresas comerciais, praças, residências, clubes, associações, restaurantes, hotéis, parques temáticos, aeroportos, etc.

5) Quanto a repercussão: intervenção no cotidiano das pessoas, estímulo à criatividade, transcendência, diversão, entretenimento, quebra de rotina, mudança de comportamento, entre outros.

Efetivamente são muitos exemplos que mostram a importância da arte, do teatro e da recreação para o turismo em nível mundial. Vale citar também os "festivais de teatro" que foram criados na Europa Medieval, com a intenção de manter o fluxo das populações feudais, nos períodos de baixa estação.

O aumento do público consumidor de arte, e também os valores artísticos e etnográficos, de um grupo ou núcleo constituem alternativas para o crescimento turístico. Esta tendência pode favorecer o "turismo artístico" e também ao lazer recreativo, internacional ou doméstico, se devidamente incentivado pelo marketing. 


\section{CAPÍTULO II}

\section{A TRAJETÓRIA DOS CÔMICOS POPULARES}

\subsection{Os cômicos populares na Historiografia}

O personagem cômico é fruto é fruto da cultura popular desde a época do Egito, antes mesmo da Grécia Antiga. Representado na literatura universal e nas histórias infantis integram o imaginário humano, assim como o riso, esclarece a dubialidade entre assuntos diversos colocados em questão por sociedades milenares que dependiam de tipos lúdicos exacerbados e satirizados com o intuito de abalar e balançar as estruturas, inserindo-se nos paradigmas mais óbvios, com o propósito de mover com os padrões.

Utilizando-se da purgação, o personagem cômico representa durante a existência das civilizações, nossa face obscura (eu interior) de aparência transmutável, personificando em bobos da corte, bufões, pierrot, arlequins, palhaços e clowns. A essência do riso (cômico/satírico); pois estes estão intimamente ligados aos aspectos obtusos da condição humana como: idiotas, deficientes e pessoas de estilos psíquicos estranhos, ensinando-nos a rir de nossas catarses, uma purgação que provoca piedade e temor através das emoções e está ligada ao trabalho do imaginário e a população da ilusão cênica. A psicanálise interpreta-a como: prazer que a pessoa colhe em suas emoções ante o espetáculo do outro.

\section{Primitividade: As Atelanas e seus personagens}

Primeiramente, na região da cidade de Atela, de colonização grega, vemos surgir as Atelanas.

Atelanas (De fabula atellana, fábulas de Atela) Fr.: atellanes; Ingl.: atellane; Atellan farces; Al.: Atellane; Esp.: atelanas.

Pequenas farsas de caráter bufão que extraem seu nome de sua cidade de origem - Atela, na Campânia. Inventadas no século II a.C., as atelanas apresentam personagens estereotipadas e grotescas: Maccus, o simplório, Buço, o glutão e 
fanfarrão, Pappus, o velho avarento e ridículo, Dossenus, filósofo corcunda e astucioso. Foram retomadas pelos comediantes romanos (que interpretavam mascarados) ou representadas como complemento das tragédias e são consideradas um dos ancestrais da Commedia dell'arte.

Nessas manifestações teatrais os atores, como os gregos, também portavam máscaras, porém improvisavam diálogos retirados e inspirados na própria relação social da época.

As "personagens" das Atelanas se caracterizavam por padrões fixos de comportamento. Sendo assim, tínhamos o "Pappus", que era um tipo bonachão e senil, vítima de piada e gozação de todos. Também encontramos "Baccus": um camponês simples e infeliz nas aventuras amorosas, idiota e guloso. "Maccus" era gordo, inchado, imbecil e vanglorioso de seus feitos. "Dossenus" era um pseudofilósofo, e achava tudo saber. Era dono de uma retórica totalmente absurda e sem nexo. (Carvalho, 1989:23).

As representações desse tipo de espetáculo eram realizadas nas ruas, e os atores, muitas vezes amadores, se inspiravam na imitação da própria população, improvisando, com isso, situações comuns da comunidade local. Representa auxiliando a desvelação de nossas misérias, o faz talvez inconsciente do aspecto transmutador dessa condição, quando através do rir, rimos de nós mesmos. O tom terapêutico acontece, mas, acho que atualmente, o clown na visão das personagens cômicas, é que intencionalmente atua com essa finalidade. Vemos aqui, claramente, o germe do que se transformaria, mais tarde, na Commedia dell'arte italiana, também com os tipos fixos de padrão de comportamento e cada ator, também, portador de máscaras.

Os tipos característicos da baixa comédia grega e romana; os bufões e bobos da idade média; os personagens fixos da Commedia dell'arte italiana; o palhaço circense e o clown possuem uma mesma essência: colocar em exposição a estupidez do ser humano, relativizando normas e verdades sociais.

Outra manifestação que tomou força em Roma foram os Mimos. Esses, diferentes das atelanas, não se utilizavam de máscaras nem mesmo de textos. Utilizavam, como meio de expressão o próprio corpo.

“O caráter essencial ficava com a expressão mímica da expressão fisionômica, do gesto e da dança. A origem desse gênero de espetáculo, assim, estaria nas danças primitivas em honra aos 
deuses, as quais imitavam os animais, os atos e as paixões do homem, os deuses da vegetação e da fecundidade, daí o seu caráter, às vezes, obsceno" (Carvalho, 1989:19).

Em ambos os casos percebemos que utilizavam como ferramenta de inspiração e criação a imitação, estilizada ou sarcástica, de homens ou animais encontrados no cotidiano.

\section{Os Mammutones}

Personagem mítico, vestido com uma pele de cabra ou de carneiro de cor preta, que levava pendurado em sua cintura, cachos de chocalhos, também ao longo das pernas, produzindo sons atormentantes. Apresentavam-se em grupos de cinco ou dez componentes. Um líder ordenava o ritmo da dança. Aparecem em rituais zoomorficos, onde se culturavam os deuses: Su boves, Su porcu.

\section{O Boccaccione}

Personagem encontrado nas comédias de Aristófanes, tinha como tarefa cênica, provocar e insultar o público, contando lorotas.

Pode ser considerado o zigoto da personagem cômica italiana, o zanni. Porém, os romanos eram mais voltados para jogos violentos, corridas, pelo circo e pelas competições de arena. Assim, no período final do Império Romano, esse teatro, talvez tentando acompanhar essa tendência popular, cada vez mais violenta e decadente, tornou-se uma manifestação degradante ou burlesca, entretanto, algumas vezes, o saltimbanco, desenvolve uma forma mais elaborada: textos satíricos, diálogos cômicos, paradas, eruditos e populares, farsas.

Hoje, com a volta do interesse popular, os saltimbancos (animadores), agitadores, oradores, vendedores) são reverenciados no teatro de rua.

Segundo Bakhtin, a cultura cômica popular da Idade Média, principalmente a cultura carnavalesca, possuía uma grande diversidade: festas públicas carnavalescas; ritos e cultos cômicos especiais; os bufões e tolos; gigantes, anões e monstros; palhaços de diversos estilos; a literatura paródica, etc. (Bakhtin, 1987: 3, 4). O riso carnavalesco abalava as estruturas do regime feudal, abolia as relações hierárquicas, igualava pessoas que provinham de condições sociais distintas. Era contrário à toda perpetuação, à toda idéia de acabamento e perfeição, mostrando a 
relatividade das verdades e autoridades no poder. Todos são passíveis de riso e ninguém é excluído dele; era a percepção do aspecto jocoso e relativo do mundo.

Os bufões e bobos, por exemplo, assistiram sempre às funções cerimoniais sérias, parodiando seus atos, construindo ao lado do mundo oficial, uma vida paralela. Estas personagens cômicas da cultura popular medieval eram os veículos permanentes e consagrados do princípio carnavalesco na via cotidiana. Os bufões e bobos não eram atores que desempenhavam seu papel no palco; ao contrário, continuavam sendo bufões e bobos em todas as circunstâncias da vida. Encarnavam uma forma especial de vida, simultaneamente real e irreal, fronteiriça entre a arte e a vida.

\section{O Bufão e os bobos da Idade Média}

Fr.: bouffon; Ingl.: fool; Al.: Narr, Esp.: bufón (gracioso).

O bufão é representado na maioria das dramaturgias cômicas. "Vertigem do cômico absoluto" (Mauron, 1964: 26), é o princípio orgiástico da vitalidade transbordante, da palavra inesgotável, da desforra do corpo sobre o espírito (Falstaff), da derrisão carnavalesca do pequeno ante o poder dos grandes (Arlequim), da cultura popular ante a cultura erudita (os Pícaro espanhóis).

O bufão, como o louco, é um marginal. Este estatuto de exterioridade o autoriza a comentar os acontecimentos impunemente, ao modo de uma espécie de paródia do coro da tragédia. Sua fala, como a do louco, é ao mesmo tempo proibida e ouvida. "Desde as profundezas da Idade Média, o louco é aquele cujo discurso não pode circular como o dos outros: do que ele diz fica o dito pelo não dito (...); ocorre também, em contrapartida, que Ihe atribuam, por oposição a todos os outros, estranhos poderes, como o de dizer uma verdade oculta, prever o futuro, o de enxergar com toda ingenuidade aquilo que a sabedoria dos outros não consegue perceber" (Foucault, 1971: 12-13).

Seu poder desconstrutor atrai os poderosos e os sábios; o rei tem seu bobo; o jovem apaixonado, seu criado; o senhor nobre da comedida espanhola, seu gracioso; Dom Quixote, seu Sancho Pança; Fausto, seu Mefisto; Wladimir, seu Estragon. O bufão destoa onde quer que vá: na corte, é plebeu; entre os doutos, dissoluto; em meio a soldados, poltrão; entre estetas, glutão; entre preciosos, grosseiro... e lá vai ele, seguindo tranqüilamente seu caminho!

Como aqueles bonecos de plástico chamados de "João bobo", o bufão nunca cai: ninguém jamais conseguirá culpá-lo ou fazer dele bode expiatório, pois 
ele é o princípio vital e corporal por excelência, um animal que se recusa a pagar pela coletividade, e que nunca tenta se fazer passar por outro (sempre mascarado, é o revelador dos outros e nunca fala em seu próprio nome, e nunca assume o papel sério dos outros, sem incorrer em sua perda). Como Arlequim, o bufão guarda, na verdade, a lembrança de suas origens infantis e simiescas. É o que nos diz o seriíssimo filósofo Adorno: "O gênero humano não conseguiu se livrar tão totalmente de sua semelhança com os animais a ponto de não poder de repente reconhecê-la e ser por isso inundado de felicidade; a linguagem das crianças e dos animais parece ser uma só. $\mathrm{Na}$ semelhança dos clows com os animais se ilumina a semelhança humana com os macacos: a constelação animal-tolo (ou louco: Narr), clown é um dos fundamentos da arte" (1974: 163).

O bufão é um ser marginal e marginalizado. Tradicionalmente ele tem deformações físicas como corcundas, um braço a menos, enormes barrigas, órgãos genitais exacerbados, são gigantes ou anões, três olhos, sete dedos. Estas deformações são como a somatização das deformações humanas interiores, das dores da humanidade, como na relação de Dorian Gray com seu quadro. O bufão é o grotesco, a manifestação exagerada dos sentidos humanos, malicioso e ingênuo, puro e cruel, romântico e libidinoso. Suas deformações físicas e seu modo de ser são como a manifestação física do tumor, da lepra das relações sociais e da pequenez humana. Seu comportamento é quase agressivo, propositadamente chocante. Ele não tem vergonhas, e assim, desde suas necessidades fisiológicas básicas até o sexo, ele as faz em público de maneira descompromissada e provocadora.

Por ser marginal e marginalizado, ele vive em grupo, ou seja, em companhia de outros bufões. A banda de bufões funciona como um coro grego, como se cada bufão fosse parte de um único organismo. Ela cria uma cultura e uma identidade própria, com regras estritas, linguagem específica e papéis bem definidos dentro da banda. Existe em toda banda um líder, seu braço direito (o puxa saco do chefe) e um idiota. Existe também a figura da pessoa externa à banca, uma pessoa "normal", que atua como a autoridade máxima a ser questionada e respeitada a qual o bufão trata com irreverência e medo.

A relação de cada indivíduo com sua banda é muito forte. O bufão tem sua força na banda. Solitário, ele é frágil e facilmente exposto às humilhações da 
sociedade. Quando um membro da banda é acariciado ou agredido, toda a banda reage, sente, como se fosse com ela.

Na Idade Média, o bufão foi um personagem de grande importância como cita A. Vesselovski, afirmando que o bufão foi o porta-voz da outra verdade,não feudal, não oficial e definiu a sua importância social, nos seguintes termos:

"Na Idade Média, o bufão é o porta-voz privado de direitos da verdade abstrata objetiva. Numa época em que toda a vida estava contida no quadro convencional dos estados, das prerrogativas, da ciência e da hierarquia escolástica, a verdade se encontrava localizada em função desse quadro e era relativamente feudal, escolar, etc.

Ela tirava a força de um determinado meio, era o produto da capacidade vital dele. A verdade feudal é o direito de oprimir o vilão, menosprezar o trabalho servil, de fazer a guerra, de caçar sobre a gleba do trabalhador, etc.; A verdade escolar é o direito ao conhecimento exclusivo fora do qual não se pode chegar a nada de bom, porque convém preservá-lo de tudo o que ameaça perturbá-lo, etc. Toda verdade universal que não coincida com algum estado ou profissão determinado, etc. com um certo direito, era eliminada, desconsiderada menosprezada e levada à fogueira à menor suspeita; só era admitida quando se apresentava sob a forma anódina, quando fazia rir e não pretendia desempenhar nenhum papel no plano sério da vida!

Foi assim que se definiu a importância social do bufão.

O bufão é grotesco e carrega em seu ser a malícia e a ingenuidade, a pureza e a crueldade, o romantismo e a libido, encarnando em si a personificação do horror e da lepra das relações sociais e da pequenez humana.

O bufão é como se fosse uma pedra preciosa em estado bruto, mostrando todas as podridões e o excremento do ser, deixando de herança para os outros personagens e tipos cômicos, a necessidade de não ter uma lógica psicológica estruturada e preestabelecida. Ele não é personagem é simplesmente um ser cômico e grotesco.

Nos séculos XV e XVI, surgiu a chamada Commedia dell'Arte ou Comédia de Máscaras. Esta típica forma de teatro do renascimento italiano teve, conforme Gassner, uma dupla origem: a arte da mímica, que brotando dos farsistas populares do período romano, evoluiu até os atores-jograis ambulantes da Idade Média e nas comédias formais de Plauto e Terêncio (Gassner, 1974, v. 1: 191). 
A Commedia dell'Arte era baseada num roteiro (canovacci), que servia como suporte para que os atores improvisassem. Este roteiro não era um texto estruturado, indicava apenas as entradas e saídas dos atores, os monólogos, os diálogos, episódios burlescos, os cantos e danças. Personagens fixos e situações codificadas facilitavam o jogo espontâneo da improvisação (Magnani, 1984: 63, 64).

\section{Os mimos}

Com o advento do cristianismo, e também em função do teatro decadente de Roma, a igreja passa a decretar concílios, anátemas e proscrições que excomungavam, não somente os atores, mas também suas mulheres e filhos. Mesmo assim o teatro conseguiu sobreviver na clandestinidade e na obscuridade através dos atores e companhias ambulantes de mimos histriões, jograis e saltimbancos. Dessa forma, os mimos retornam à vida primitiva e errante, um tipo especial de teatro, vindo da atelana primitiva, logo irá constituir a commedia dell'arte, a primeira grande escola de ator na evolução da história do teatro (Carvalho, 1989: 28).

\section{Os Saltimbancos e Mambembes (século XV e XVI na Europa)}

Mambembe: é originalmente, um dançarino de teatro. A palavra (no original francês) vem do latim vulgar ballare. Designa hoje o saltimbanco. Trupes mambembes de histriões e saltimbancos cruzaram antigamente a Europa realizando espetáculos populares em tablados. Esses atores (palhaços), acrobatas, cantores, poetas, malabaristas, se apresentavam sempre à margem do teatro oficial.

Saltimbancos: O saltimbanco era um artista popular, que, nas praças públicas, quase sempre em cima de um tablado, fazia demonstrações de habilidades físicas, de acrobacias de teatro improvisado, antes de vender ao público objetos variados, pomadas ou medicamentos.

Saltimbanco é o termo genérico para malabarista, pelotequeiro, embustero, charlatão, farsante, pregoeiro.

$\mathrm{Na}$ Idade Média, os saltimbancos se reuniam nos lugares de passagem de pessoas mais freqüentes: em Paris, em Veneza, etc. São representantes de um teatro não literário, popular e assumidamente satírico e político. O espetáculo é gratuito e é de encontro das classes populares, mas também, as vezes, de aristocratas que não se furtavam a se misturar ao populacho. 
O espetáculo dos saltimbancos, na maioria das vezes, é baseado numa performance física, e não na produção de um sentido textual ou simbólico. Os procedimentos se baseiam numa habilidade física.

\section{O Zanni e sua origem Italiana}

A origem da palavra, data dos séculos XV e XVI.

Personagens dos carnavais venezianos nomeados pelos camponeses do vale do Rio Pó, na região de Bérgamo. Deriva do nome Gianni ou Giovanni. Está ligado profundamente a história de Veneza.

O Zanni era considerado o verdadeiro faminto, tinha fome de tudo: comida, poder, mulheres, objetos, etc.

Era um criado cômico. E apresentava-se em duas personagens, complementares: um bobo e o outro esperto e astuto, originando assim o Arlequim italiano.

Sua vestimenta era bastante vasta, apresentando-se em três tipos básicos, diferenciados pelos trajes cômicos: trajes com formas delineadas com ornamentos, cores diversas entre um paletó e uma calça, ou roupas velhas de seus patrões.

As denominações acompanhariam e transformariam-se em cada região da Itália e França: Arlechino, Trufaldino, Trivellino, Tostellino, Fogattino, Polpettino, Bertollino, Nespolino, Treppollino, Zaccagino, Bagolleno, Pedrollino, Frittulino, Tabachino.

É considerado o pai do Arlequim.

Embora mascarados e tipificados, eram fortemente individualizados quanto à fala e dialeto. Geralmente, os intérpretes assumiam seus papéis por toda a vida (Gassner, 1974, v. 1: 191).

Já na Commedia dell'Arte, apareceram, de certa forma, resquícios da dupla de cômicos, nos Zanni, servos da Commedia dell'Arte, cuja relação se aperfeiçoará nos clowns. A eles cabia a tarefa de provocar o maior número de cenas cômicas, por suas atitudes ambíguas e suas trabalhadas e trejeitos. Existiam dois tipos distintos de zanne: o primeiro fazia o público rir por sua astúcia, inteligência e engenhosidade. De respostas espirituosas, era arguto o suficiente para fazer intrigas, blefar e enganar os patrões. Já o segundo tipo de criado era insensato, confuso e tolo. Na prática, porém, havia uma certa "contaminação" de um com o 
outro. O primeiro zanni é mais conhecido como Brighella e o segundo como Arlecchino.

Este teatro teve grande aceitação na época, pois era do universo cotidiano do público que os atores tiravam a base para sua representação. Fazia descrições vivas de tipos característicos e costumes contemporâneos, envoltas em tramas de intrigas amorosa. Os velhos eram satirizados como tolos e intermináveis variações eram introduzidas no tema da traição e do marido traído.

As personagens eram fixas e possuíam máscaras próprias, cujas linhas revelaram o caráter pessoal de cada um. As principais eram: Pantalone, o velho rico e tolo mercador de Veneza; Dottore, personificação do pedantismo dos intelectuais da época; Capitão Mata-Mouros, soldado fanfarrão e covarde, metido a valente; Arlecchino, servo esfomeado e atrapalhado; Brighella, servo astuto e briguento; Pulcinella, ora servo, ora patrão, de índole cruel e violenta; Os Enamorados, jovens apaixonados e sensíveis.

Pelas características acima descritas, não é difícil relacionar a dupla de zanni à dupla de clowns circenses.

A essência do circo acompanha desde muito o cotidiano do homem. Segundo Ruiz, pesquisadores afirmam que o ano de 70 a.C., em Pompéia, já existia um enorme anfiteatro destinado a exibições de habilidades que posteriormente seriam caracterizadas como circenses. Por outro lado, na China, já por volta de 200 a.C., as artes acrobáticas se encontravam em desenvolvimento. Números até hoje tradicionais, como equilíbrio sobre corda bamba, magia, engolir espadas e fogo, já eram conhecidos e praticados, nessa época, pelos chineses (Ruiz, 1987: 14, 15, 16).

\section{Arlequim}

Esta personagem cômica é uma das mais famosas máscaras da Commedia Dell'arte nos séculos XVII, XVIII.

No geral é tosco e ingênuo, esperado como um macaco, ágil como um gato e violento como um urso enfurecido, adotando assim características de animais.

Sua personalidade é muito vulnerável. Com as mulheres age de forma graciosa e ingênua, mas sua convivência com os homens é de perversa maldade. 
Incapaz de pensar em mais de uma coisa nos momentos em que faz suas artimanhas, ele tenta resolver suas idéias e trapaças no mesmo momento, colocando-as em prática, porém são raras as vezes em que ele inicia uma intriga.

É considerado um camaleão devido à facilidade de se disfarçar e travestirse.

Apresenta em seu traje, cores variadas, cortadas em formas geométricas e também rasgos, dando impressão de uma roupa rasgada e velha, o que facilita seu trabalho corporal, destacando assim a sua agilidade e acrobacia. Sua máscara facial é zoomórfica na junção de macaco com gato, de cor preta, uma faca como objeto de cena.

Trabalha sempre com a ironia em seus pensamentos e também com a improvisação.

\section{Pierrot: A comicidade ingênua francesa}

Personagem de origem francesa que se assemelha psicologicamente com o Arlequim italiano.

Suas intrigas são sempre dirigidas a favor de seu amo.

A indumentária inicial se parecia com a do Zanni: roupas largas, com mangas compridas e frouxas no corpo, pompons e guizos.

Molière contribuiu bastante para a popularização do Pierrot.

Sua personalidade, se voltava para observar a vida cotidiana parisiense. Preguiçoso e puro, apresentava-se como uma figura estática, apesar de uma franqueza e estupidez calculada.

\section{Palhaço: O riso personificado (século XVIII e XIX)}

Palavra que vem do italiano paglia (palha), material utilizado no revestimento de colchões. Tal denominação foi dada a essa personagem cômica, devido a sua vestimenta inicial, ser feita de um tecido grosso e listrado, afofado nas partes salientes do corpo, fazendo de quem a vestia um verdadeiro "colchão" ambulante, protegendo-o de suas constantes quedas.

Este artista, atua em espetáculos circenses ou em outros, se veste de maneira grotesca, e faz peripéias e momices para divertir o público. 
Shklovski relata em seu texto a importância do palhaço, e na tese de Luiz Otávio Burnier, a idéia se confirma:

"Os palhaços sempre foram parte integrante do circo. Num espetáculo de perícia física, que produz na assistência uma reação mental, deslumbramento, espanto, admiração e apreensão, é preciso haver em complemento um conceito mental que produza no público uma reação física, ou seja, o riso" (Coxe, 1988: 6). (Burnier, 1994:29).

Walter Seyssel, o Arrelia, membro de uma tradicional família circense francesa, cujo pai, tio e avô foram renomados clowns, narra em seu livro "Arrelia e o Circo", como foi o seu batismo e a sua iniciação. É importante notar que embora tenham ocorrido de forma natural, ambos significaram uma exposição ao ridículo de Waldemar:

"Quando o trem partiu da cidade, meu tio veio até o vagão onde eu estava com a rapaziada do circo, zangado, disse:

- Vamos ver qual é a encrenca que você vai arranjar na próxima cidade, "seu" arreliento! Vê se para com essas arrelias, ouviu?

Daí para diante fiquei sendo o "Arrelia" da turma! Quanto mais furioso ficava quando me chamavam de Arrelia, mais o apelido pegava. Até minha mãe, quando ficava zangada comigo, exclamava:

- Você é mesmo um "arrelia"!

E eu não me conformava!

Mal sabia que, mais tarde, esse seria um apelido de sorte.

$\mathrm{Na}$ ocasião em que o apelido de "Arrelia ficou sendo minha marca profissional, nosso circo já era de propriedade de meu pai e de um dos seus irmãos, Vicente Seyssel. Tio Vicente já fora "companheiro de dupla" de palhaços muito conhecidos, como o falecido Alcebíades Albano Pereira, um dos "clowns" mais famosos do Brasil. Era um bom músico e tocava pistão como poucos o faziam naquela época.

Isto aconteceu tempos depois daquela briga que me valeu o apelido. Numa das minhas vindas da escola para o circo, para passar as férias, encontrei meu pai cansado e meio adoentado. Ele passava procurando um substituto para ocupar seu lugar, isto é, para ocupar o lugar do palhaço Pingapulha. Tinha colocado à prova todos os meus irmãos mais velhos, mas, por mais que eles se esforçassem, nenhum Ihe agradara e nem agradara ao público. 
Cheguei...e foi a minha vez de ser posto à prova. Pintaram meu rosto, deram-me uma roupa grandalhona, umas calças muito largas e uns sapatos enormes. Eu não queria entrar, pois ninguém ensaiava nada comigo! Todavia, essa falta de ensaio também fazia parte da prova e do papel que eu ia representar; ia ser o improvisador da noite, o chamado "Tony da Soirée".

Numa algazarra danada, jogaram-me para dentro do picadeiro. Não sei se caí de mau jeito ou em cima de uma pedrinha... ou sei lá o quê! o que sei é que doeu! Levantei-me capengando e devo ter feito isso de forma muito engraçada pois o público riu a valer - talvez da minha roupa, talvez da minha expressão de dolorida atrapalhação, que sem dúvida devia parecer muito "autêntica".

Sem saber o que fazer, aproximei-me de um dos meus irmãos, que ajudava a armar um aparelho para a próxima representação; baixinho, perguntei:

- O que é que eu faço agora?!

Meu irmão sugeriu:

- Vá lá e derruba o Benedito.

Benedito era um pretinho "amarra-cachorro", que, justo nesse momento, estava enrolando um tapete, distraído e bem a jeito para colaborar no meu "improviso". Foi o que fiz! Corri e empurrei o coitado, que caiu e se embolou com o tapete. Logo, porém, levantou-se e, querendo cooperar comigo, deu-me um empurrão... mas com tal força que eu - que não esperava - fui parar em cima de uma família que estava sentada na fila de cadeiras situada bem em frente ao picadeiro. Derrubei a família inteira! Foi um bolo danado e o público a rir cada vez mais.

Levantei-me e pedi perdão ao chefe de família. Chamando-me de palhaço bobo, ele me empurrou; fui para trás, tropecei, bati as costas nas tábuas que rodeavam o picadeiro e levei um tombo. O machucado anterior voltou a doer. Voltei a mancar... e o povo rindo... Com muita raiva do pretinho "amarra cachorro", resolvi dar-lhe um daqueles tapas que nós, de circo, chamamos de "claque"; o que dá a bofetada leva a mão no rosto do outro e este - fingindo receber o tapa - recua a cabeça para trás e dá uma palmada embaixo, com as próprias mãos. O efeito é o de uma verdadeira bofetada.

Dei o tal "claque" no pretinho. Ele, porém, não era versado nas artes circenses e não sabia que tinha que bater com as duas mãos, a fim de produzir o ruído de uma bofetada. Como ele não respondesse naquela primeira vez, eu, que já 
estava de mal-humor, dei-Ihe uma segunda tapona... mas pra valer! O pretinho, com a força do golpe, caiu e olhou vesgo para mim. Recompôs-se do tombo e do tapa, levantou-se, pegou um pedaço de pau que estava ali por perto... e veio com uma tal cara de ódio para cima de mim, que não tive outro meio, senão sair correndo... e o pretinho atrás de mim... e o povo rindo!

Meus irmãos também riam, pensando que aquilo era graça. Eu, porém, sabia que o caso não tinha graça nenhuma e que, se o pretinho me pegasse, iria levar a maior surra da paróquia! Corria por cima das bancadas do circo, pelo meio do povo e o danado do pretinho atrás de mim, dizendo palavrões! O povo quase rebentava de tanto rir. Felizmente, numa das correrias, pude chegar até perto de meu irmão mais velho. Assustado e sem fôlego, implorei:

- Segura o preto que ele me mata!

Foi aí que meus irmãos viram que não era graça, não! O pretinho foi agarrado e levado para dentro, a muito custo, arfando de tanto exercício. O público ria e aplaudia a minha cena, que fora... improvisada. Daí para diante fiquei sendo o palhaço Arrelia - isto depois de tudo ter sido serenado com o pretinho, que aprendeu a levar bofetadas. Para novas apresentações daquela cena ao público, uma família de comparsas, do próprio circo, era posta nas cadeiras da frente. $O$ número ficou sendo uma das atrações da noite de estréia, nas localidades por nós visitadas" (Seyssel, 1977: 23, 24, 25).

\section{O clown: $O$ remédio da sociedade pós-moderna}

Segundo Roberto Ruiz a palavra clown vem de "clod" que se liga, etimologicamente, ao termo inglês "camponês" e ao seu meio rústico, a terra. (Ruiz, 1987:12). Os exímios cavaleiros que formavam a troupe de Astley em 1772, no célebre "Número do Recruta da Cavalaria", simulavam camponeses, simplórios e astutos, provocando com suas extravagâncias, a hilaridade nas platéias (Ruiz, 1987:12).

O clown tem suas raízes na baixa comédia grega e romana, com seus tipos característicos, e nas apresentações da Commedia dell'Arte (Ruiz, 1987:15). Nas festividades religiosas e nas apresentações populares da antiguidade havia uma alternância entre o solene e o grotesco. Este é um fato comum a povos distintos: dos 
gregos até os aborígenes da Nova Guiné, passando pelos europeus da Idade Média ou pelos Lamaístas do Tibete.

Existem dois tipos clássicos de clowns: o branco e o augusto. O clown branco é a encarnação do patrão, o intelectual, a pessoa cerebral. Tradicionalmente, tem rosto branco, vestimenta de lantejoulas (herdada do Arlequim da Commedia dell'Arte), chapéu cônico e está sempre pronto a ludibriar seu parceiro em cena. Mais modernamente, ele se apresenta de smoking e gravatinha borboleta e é chamado de cabaretier.

O augusto (no Brasil, Tony ou Tony-excêntrico) é o bobo, o eterno perdedor, o ingênuo de boa-fé, o emocional. Ele está sempre sujeito ao domínio do branco, mas, geralmente, supero-o, fazendo triunfar a pureza sobre a malícia, o bem sobre o mal, Adoum (1988) afirma que a relação destes dois tipos de clowns acaba representando cabalmente a sociedade e o sistema e isto provoca a identificação do público com o menos favorecido, o augusto.

É interessante notar que existe maior riqueza na comicidade quando os dois tipos atuam em dupla, pois um serve de contraponto ao outro. Eles são encontrados tanto nos espetáculos circenses da Inglaterra, como nos dois zanni da Commedia dell'Arte.

O clown também desempenha função semelhante à dos bufões e bobos medievais, quando brinca com as instituições e valores oficiais. Ele, pelos nomes que ostenta, pelas roupas que veste, pela maquiagem (deformação do rosto), pelos gestos, falas e traços que o caracterizam, sugere a falta de compromisso com qualquer estilo de vida, ideal ou instituição. É um ser ingênuo e ridículo; entretanto, seu descomprometimento e aparente ingenuidade lhe dão poder de zombar de tudo e de todos, impunemente.

Assim o princípio desmistificador do riso, presente na cultura popular medieval renascentista, apareceu no cômico circense, fundamentada basicamente na figura do palhaço.

Em suas andanças através do tempo, o clown ocupou diversos espaços: a rua, a praça, a feira, o picadeiro, o palco. Com o advento do cinema, no início do século $\mathrm{XX}$, ele encontrou um novo lugar para continuar revelando à humanidade seu lado ridículo e patético.

O primeiro clown do cinema foi o francês Gabrielli Leuvielle, que tem por pseudônimo Max Linder. Ele dirigia e atuava em seus filmes. Exatamente como os 
clowns Max Linder utilizava tudo o que sabia fazer (dançar, saltar, montar a cavalo, etc.). Sua motivação era o desejo de fazer um número circense, exemplo que será seguido por todos os seus sucessores até Jerry Lewis. Os argumentos que ele tinha por tema eram sempre, como nas entradas de clowns, extremamente simples. Eram as sucessões de gags que mantinham o interesse; o roteiro não passava de um pretexto para criação de situações cômicas, assim como na Commedia dell'Arte. Max Linder buscou sua inspiração no teatro de Vaudeville (Teatro cômico musical, apresentado em bares e cabarés). E, sobretudo, no circo. (Etaix, 1982: 159).

Os clowns do cinema retomaram diversas gags já usadas anteriormente por outros colegas de cinema ou por clowns de circo. Assim Chaplin, em "Em busca do Ouro", na "dança dos pequenos pães" se inspirou nos fantoches de barracas de feiras. "Nada mais natural, pois este costume vem justamente do circo, onde, ao redor das mesmas receitas, brilham os cozinheiros de diferentes gostos” (Etaix, '982: 161).

Com freqüência os cômicos do cinema transportavam diretamente para seu veículo um trabalho que era próprio do circo. Todos esses cômicos foram formados nas escolas do circo e no music-hall. Cada um deles era acrobata, dançarino, malabarista, cuspidor de fogo, mímico. E é bastante normal que eles retenham de suas origens tudo o que pode enriquecer esta nova arte: o cinema.

Como nos clowns do circo europeu, eles criaram para o cinema tipos originais e únicos - contrariamente ao comediante, que deve poder encarnar personagens os mais diversos. Assim, Carlitos é o clown de Chaplin, pessoal e único,não importando se desempenha o papel de "O Grande Ditador", do vagabundo de "O Garoto" ou do operário em "Tempos Modernos".

Do ponto de vista da técnica do clown utilizada, alguns desses tipos do cinema chegaram a um grande nível de requinte. Dentre eles, destacaria Charles Chaplin, a dupla Hardy e Laurel (O Gordo e o Magro), Buster Keaton, Harold Lloyd, Jacques Tati, Jerry Lewis, Mazzaropi, Oscarito, Grande Otelo e outros.

O clown é a exposição do ridículo e das fraquezas de cada um, logo, ele é um tipo pessoal e único. Assim, uma pessoa pode ter tendências ao clown branco ou ao clown augusto, dependendo de sua personalidade. O clown, portanto, não representa, ele é - o que faz lembrar os bobos e os bufões da Idade Média. Não se trata de um personagem, ou seja, uma entidade externa a nós, mas da ampliação e dilatação dos aspectos ingênuos, puros e humanos (como nos clods), portanto 
"estúpidos" do nosso próprio ser. François Fratellini, membro de tradicional família de clowns europeus, dizia: "No teatro os comediantes fazem de conta. Nós, os clowns, fazemos as coisas de verdade". (Etaix, 1982: 162).

O trabalho de criação de um clown é extremamente doloroso, pois confronta o artista consigo mesmo, colocando à mostra os recantos escondidos de sua pessoa; vem daí seu caráter profundamente humano.

Para o público rir, o clown chora. Engibarov, clown russo, diz:

"O clown faz tudo, sempre, seriamente. Por certo, isto não significa que não queira ser cômico. Ao contrário, usa meta é fazer rir. Mas o verdadeiro cômico consegue isso sem tentar fazer rir a qualquer preço. (Engibarov, 1988: 17).

O clown busca essa sinceridade e essa corporeidade do seu ridículo e de sua ingenuidade, para mergulhar em si e ter a coragem de encontrar estados humanos, transformando-os em riso. Verifica-se no clown a possibilidade de entrar em contato com uma energia sutil, lírica e delicada. O prazer de simplesmente ser.

Na verdade, o riso é simplesmente uma conseqüência desses elementos e desse estado puro do clown.

\section{A commedia dell'arte e a improvisação: A revolução do lúdico}

A improvisação é um elemento onipresente em toda representação teatral e nos artistas populares. Comparece em qualquer ato de desempenho cênico, desde o mais espontâneo até o mais trabalhado em termos formais, quer no decurso do processamento, quer no produto final da obra encenada. Pode-se afirmar que o elemento improvisacional é uma constante e, em maior ou menor grau - numa graduação que envolve, além de temperamento e aptidão, gênero e estilo, técnica e treinamento.

A técnica da improvisação como meio para chegar à escolha mais adequada (natural) é melhor (representativa) da atuação deliberada foi proposta por Stanislavski, grande diretor russo e sistematizador de técnicas teatrais para atores:

"Os intérpretes devem fazer uso da improvisação não apenas durante os ensaios de uma peça, a fim de entrarem numa personagem a ser apresentada e promoverem o processo de sua definição cênica, mas também como exercício de desenvolvimento de suas potencialidades físicas emocionais, imaginativas e 
sensitivas. O poder e a liberdade criativos são fortemente impulsionados com os improvisos".

De qualquer modo, o "espírito da improvisação" - deve acompanhar sempre o comediante quando ele se lança a qualquer tipo de atuação no palco, ou nas ruas, pois a resposta bio-psico-energética da proposta representativa terá de vir do espírito livre daquele que atua. Aí está contida toda a liberdade criadora do intérprete artista.

E no gênero cômico que a improvisação atinge maior explicitação, graças à natureza extrovertida do ritmo interpretativo, ao inverso do gênero trágico e do drama, sempre mais presos ao texto literário e à interpretação mais introspectiva das personagens. O teatro que enfatiza a relação palco/platéia, como o de participação do público, terá maior espaço para o emprego da improvisação explícita, principalmente no âmbito coletivo. Haverá mais ensejo de surpresas e imprevistos no decorrer das cenas, visto que uma das partes, o conjunto de espectadores, está desarmada, isto é, não se programou previamente para executar ações teatrais. A improvisação, enquanto gênero, encontrou no curso de seu processamento histórico, expressão e feição em diferentes modalidades peculiares, como os mimos e as atelanas da antiguidade grego-latinas, a farsa e o teatro de feira na época medieval, até atingir o apogeu e a máxima grandeza na commédia dell'Arte. Esta por sua vez, irá influenciar a pantomima romântica e todo o teatro moderno, quer no que concerne às formas cênicas, quer na busca de uma relação participativa com 0 público ou na preparação do comediante.

Considerando ser o teatro a arte da mímica: expressão fisionômica, gesticulação, plasticidade, agilidade, volubilidade, pode dizer-se haver a Itália possuído o gênio do teatro. Incapaz de ter um sentido trágico original mas repleto de virtuosismo na representação cômica, manteve, por meio de uma ginástica capaz de dar maleabilidade e retemperando-se nas fontes populares, a arte dramática em forma.

Sobre a Praça de S. Marcos, em Veneza, uma multidão de Charlatães se apresenta, fazendo habilidades. Esta feira permanente, é o próprio Teatro prosperando na rua e alimentando-se dela. Herdeiros diretos dos mimos errantes da Antiguidade, os bufões percorrem a província. Sempre a Igreja lhes fez guerra; 
souberam, porém, imiscuir-se nas festas, tomando a seu cargo a representação dos diabos. Arlequim, na Idade Média, não era o rei infernal, Hell-Konig, Helquim?

Das chamas eternas que calcinaram esses rostos são testemunho a máscara negra e o nariz achatado como os dos sátiros. Seres amaldiçoados esses feiticeiros, os seus corpos fascinam trazendo consigo o mistério dos países estranhos.

Recebidos pelos príncipes, participam nos espetáculos da corte. A juventude imita-os. Os acadêmicos - grupos de amadores ou dilettanti - começam a improvisar pequenas revistas de atualidades. Meio século passa. Em 1586, na presença do duque da Baviera, Massino Trojana e o músico Roland de Lassus representavam uma comédia ensaiada num dia. Tudo já aí se encontra: música, lazzis e danças, bem como Pantalão, Zane e Isabel, mais o espanhol ciumento. A corte francesa moldando-se ao gosto das princesas florentinas, fez dos Ganassa e dos Baltazarini os grandes organizadores das festas. O Ballet Comique de la Reine (1581) marcou uma data.

$\mathrm{Na}$ Itália, a fórmula nova não tardou que suplantasse qualquer outro gênero de comédia. Vinda da rua mas formada nos palácios, voltou a apresentar-se ao povo no seu melhor aspecto: companhias regulares, teatros bem equipados, instrumento rico e recursos.

Deixava-se ainda classificar de populare, para distinguir-se da erudita, mas o nome de commedia dell'arte, que Ihe era dado pelos do métier, de commedia a soggetto ou de improviso definem muito mais exatamente aquilo que ela era.

Estrutura da commedia dell'arte: Os cenários conhecemo-los através de algumas recolhas como a de Gherardi, podendo assim fazer-se idéia de mais de meio milhar de peças. Os assuntos são quase todos tirados do fundo já elaborado da literatura antiga e moderna: comédias, romances, pastorais, contos, etc., percorrendo todo o registro, desde a farsa ao melodrama.

Três atos precedidos de um prólogo, este sem ligação alguma com a peça, dez a doze personagens além dos comparsas; a intriga embrulhada e desembrulhada com uma presteza louca a meio de um verdadeiro carnaval de marcações: rixas, acessos de loucura, duelos, perseguições, aparições, pancadaria, tiros de pistola, disfarces, raptos, etc. Quanto aos famosos lazzis eram trechos de bravura para os atores, solos de canto, danças, acrobacias, pantomima, por vezes simples figuras (por exemplo, dois criados ligados costas com costas tentando 
alternadamente lamber um prato de maçarão colocado no chão). Bem entendido, tais números tendiam a desenvolver-se por si sós, sendo servidos como suplemento à peça.

O concertatore ou corago tinha por fim orquestrar tantos motivos diversos, sem prejudicar o momento. A intriga só era pedido que permitisse realçar o talento do intérprete, a parte importante da invenção real, mesmo quanto à observação dos tipos e costumes, sendo deixada ao seu gênio.

Improvisava o ator todo o seu texto? Geralmente, à parte as saídas que o diabo Ihe soprava ao ouvido, ou nascidas a propósito de quaisquer incidentes, todos os efeitos eram premeditados cuidadosamente - mantendo-se, no entanto, o ator juiz supremo das liberdades que se permitiam. A inspiração bebia-a principalmente na Literatura. Coleções de ditos de espírito, de canções, de pensamento (concetti) comparações e monólogos guarneciam-Ihe a retórica. Existiam também tradições da profissão, efeitos seguros que passavam do professor ao discípulo articulando a representação de cada ator, no conjunto.

Mesmo quando se expandia em rio precipitado, a palavra não comandava a representação, tendo quando muito o ar de nascer dela. De qualquer maneira só executava a parte que lhe era destinada, no conjunto. Por outro lado, o fato de o ator vir mascarado forçava-o a alargar a mímica a todo o corpo, fazendo-se quase dança. Deste modo o natural obedecia à fantasia e a virtuosidade preservava a espontaneidade.

Os tipos fixos - é um ponto ainda a apurar saber se o Zane bolonhês e Bergamasco descende do Sannio, da Atellane, ou se é apenas Giovanni, espécie de João 0 Pateta, Zampiro, Zancarlo, conforme é designado na Lombardia. Seja, porém, como for, o fato é este Zane ter origem camponesa, sendo o irmão mais novo dos camponeses o que Ruzzane, em 1520, fazia falar com a pronúncia cerrada dos Paduanos e Calmi com o sotaque veneziano. Esses Zani transformaram-se em criados sob a influência erudita, dividindo-se, nessa altura, o tipo. Passou a haver o velhaco (primeiro Zane) e o lapus (segundo Zane). Tanto em Veneza como em Nápoles, o camponês resolvera meter mãos à obra e dedicar-se ao negócio, empregando-se em trabalhos do porto. A esperança do ganho atraía-o, a aventura embriagava-o um pouco, sem Ihe fazer, no entanto, perder a cabeça. Nas cidades onde existiam universidades, o serviço do amor assegurava-lhe uma inesgotável clientela. Covielle e Scaramouche são naturais de Nápoles: Brighella, Messétio e 
Arlequim, de Bérgamo; outros personagens virão de Bolonha e ainda alguns serão originários sabe-se lá donde, de tal modo estão já confundidos e misturados, constituindo um verdadeiro enxame: Truffaldim, Trivélia, Scapim, Francatrippa, Tabarim, Tartaglia o gago (primeiro ministro de Gozz), Buratino, epónimo dos bonecos articulados, Pasquim, Farfanicchio, etc., todos eles lambões, palradores, mentirosos, ladrões, poltrões mas ágeis, infatigáveis, não se atrapalhando nunca. Pedrolino e Arlequim tiveram, em França, uma carreira à parte. O primeiro transformado em Pierrot, conservou no entanto da origem o blusão e as calças brancas. Watteau emprestou-lhe o chapéu triangular dos Zani e o Romantismo atribuiu-Ihe lunar melancolia. Quanto a Arlequim, estreara-se ao serviço de um amo avarento; os remendos do seu fato o demonstram antes de haver-se transformado em ornamento. Uma vez em Paris, depôs a máscara de couro negro e farta bigodeira, que a ninguém agradavam, fazendo-se D.Juan, sem que isso o levasse a perder o sentido dos outros negócios a que sempre se dedicara. A figura napolitana de Polichinella, destinada a alegrar as farsas onde a política tinha a última palavra, aparece também na forma de fantoche. Foi com esse aspecto que Londres o adaptou, chamando-Ihe Punch. Em França Polichinelo entrou em relações com Guignol, nascido em Lião, no século XVIII, confundindo-se com ele. O Hanswurst alemão, o Kasperl de Viena são seus primos, bem como o Petrouchka russo.

O fidalgo Pantalon é um pouco o Maccus da Attelane; mas, ainda mais, o veneziano enriquecido pelo tráfico marítimo: um velho sovina, libidinoso quando calha e eternamente intrujado. O Capitan (Fracasso, Matamouros, Rinoceronte, etc.) é o espanhol ou o retre suíço, terror dos pobres camponeses. Na figura do Doutor, descendente de Dosseno da Campânia, encontra-se encarnada a escolástica maçadora.

Fortuna e posteridade da comédia - Incapaz de renovar-se, a commedia dell'arte declinou lentamente. Cedera à ópera a sua maquinaria e bailados e, por sua vez, a comédia regular, à qual tanto roubara, vem pilhá-la também.

$\mathrm{Na}$ Itália encontrou, já um pouco tarde, escritores que lhe asseguraram uma poltrona na Academia, um lugar na Literatura. Foram eles dois venezianos: Goldoni (1707-1790), que muito tempo exerceu, em França, a sua pena de improvisador e Gozzi (1720-1806) mestre no gênero féerie (fiebeque) - A Princesa Turandot.

Os verdadeiros títulos de glória a Commedia pode pedi-los à posterioridade. Tracemos um quadro sucinto. 
De um modo geral deve-se muito à comédia italiana todo o teatro:

a) onde a idéia e o sentimento importam menos do que a ação;

b) Onde a ação se liberta em movimento cênico;

c) Onde a personalidade do atos tem importância preponderante.

Ou, então, em diversos aspectos:

- As peças com qüiproquós e golpes de teatro (comédia de intriga, melodrama, vaudeville, moderno).

- A comédia cantada e dançada.

- A comédia com intermezos (comédia-ballet)

- O bailado em todas as suas formas.

A ópera, ópera-cômica, ópera-bufa, opereta, vaudeville cantado.

- Todo o teatro de caráter ou aparência popular: truões franceses do século XVIII; teatro de feira, teatro de bulevar (século XIX), melodramas e féeries românticas e as célebres pantomimas do funâmbulos, arte reinventada por João Gaspar Debureau; mais tarde as peças do repertório do Chatelet, desde As Pípulas do Diabo até a A Volta ao Mundo em Oitenta Dias.

- O circo (especialmente os intermezos dos palhaços) e, de um modo geral, todas as variedades do music-hall.

- O teatro mecânico: a) os marionetes; b) o cinema; maravilhoso desenvolvimento do teatro de sombras e da pantomima (Charlot). Os gags são os lazzis do humor anglo-saxão.

- As entrevistas, reportagens e representações radiofônicas.

- A mise-em-scéne moderna, na medida em que disciplina a representação, combina todas as técnicas da cena, procura traduzir o texto em valores plásticos e rítmicos, tendendo, no fim de contas, para o teatro puro.

A commedia dell'arte - século XVI até meados do século XVIII - é sem dúvida a mais significativa moldagem do gênero improvisacional de que se tem conhecimento, tendo por isso mesmo se tornado um de seus principais paradigmas. Baseada exclusivamente na arte do ator e na fixação de personagens-tipo (máscaras), tem suas raízes nas farsas atelanas cuja tipologia desenvolveu. Em oposição ao teatro literário, os cômicos dell'arte, do ofício, sustentavam que o autor é ator. A commedia dell'arte eleva a improvisação à categoria do artístico. Os improvisadores possuem de fato competência e preparo para a modalidade de atuação a que se propõem, sendo verdadeiros artistas cômicos. Com vistas ao 
contato direto com a assistência, trazem para o tablado um roteiro mais ou menos esboçado por escrito, a partir do qual preenchem o corpo da cena com seu fazer teatral. A relação do teatro do palco com a peça escrita e da ação cênica com a platéia tem caracterizado o gênero improvisacional no decorrer da história. É a maior ou menor extensão e acabamento do script textual e da representação programada que vem suscitar os graus da improvisação.

De caráter popular, compunha-se de quadros curtos e rápidos, sobre temas do dia-a-dia, aproveitando as situações do momento, como acontece sempre nesta variedade de tablado. Armado pelos mimos nas feiras, em vinculação direta e em troca ao vivo com o seu público, o espetáculo do improviso configurará um gênero de teatro que jamais interrompeu a sua função, correndo em paralelo ao teatro textualizado pela literatura dramática, até os nossos dias.

Assim, pode-se concluir que a improvisação não é um fenômeno fortuito na linguagem e na incorporação da cena. Presente em todo ato interpretativo e até seminal para a sua efetividade, ela não se exprime apenas neste nível, nem nó de uma reles forma marginal de performance cênica. Dependendo da gradação em que for empregada, assumirá diferentes feições, chegando mesmo a articular-se como gênero por direito próprio na arte de representação teatral. Sua onipresença, no palco, é histórica e estética.

\section{A presença de um teatro cômico popular no DF: Histórias, atualidades, tendências e sua ação no turismo}

O teatro cômico tem a qualidade e a dor do efêmero. Qualidade por ser uma experiência irrepitível e inadiável. Um espetáculo teatral se esgota no tempo do pavio de uma vela, teatro é algo vivo e pulsante, é emoção, respiração, transpiração.

O teatro cômico brasiliense, pulsa desde a criação da cidade, na voz e nos gestos de seus candangos, que moravam na "cidade livre" até nossos dias, com muitos grupos fazendo sucesso fora da cidade. A cidade nasceu com sua gente e sua cultura diversificada, somos espectadores e personagens deste teatro cômico popular, deste besteirol social.

Sonhos desfilam por nossas lembranças que apresentam um teatro forte e viril, de forma cômica, crítica e satírica, na luta política pela igualdade social e pela 
liberdade. Grandes experiências catárticas, grandes performances cênicas e líricas fazem parte da história que nem bem começou e já é capaz de oferecer um pouco de identidade a esta terra feita sobre tantas identidades e sobre tantas diferenças.

A comédia popular de Brasília reúne experiências de grandes artistas como: Hugo Rodas, Ary-Para Raios, Udigrudi, os melhores do mundo, Cláudio Falcão, Escola de Bufões e outros.

Neste tópico sobre o teatro popular brasiliense, vou trazer trechos de entrevistas de 3 artistas brasilienses, que dedicaram e dedicam suas pesquisas a esta forma de teatro e expressão artística que freqüenta e é feita para as pessoas da rua, e da cultura popular:

O primeiro, é Ary Pára-Raios, já falecido, que conta um pouco a história do teatro brasiliense e também a história de sucesso de seu grupo "Esquadrão da vida" - 23 anos fazendo palhaçadas. O segundo, muito conhecido na cidade, por seus espetáculos, e sua grande influência no teatro de mameluco, e na valorização da cultura popular, é Chico Simões. O terceiro escolhido, é Ricardo Gutti, que em suas trajetórias teatrais está buscando uma nova estética popular para o teatro brasiliense.

Então vamos a seus depoimentos:

Ary Pára-Raios: foi ator, palhaço, jornalista, crítico encenador e diretor fundador e integrante do esquadrão da vida.

“... considerando que a paisagem urbana de Brasília, cidade que nós amamos, é a mais inclemente em termos de escala com a figura humana, assim como o cerrado. É muito fácil fazer espetáculos na rua em qualquer outra cidade para quem vence Brasília no aspecto espacial.

Isso foi deixando nossas veleidades vanguardistas tais, todas de lado, e nós fomos virando gente de rua, do gesto, das confusões metafísicas, das expansões físicas do gesto, da voz para trabalhar na rua, onde não é muito simples. Cada vez que se trabalha se descobre que é mais difícil, porque se você não vai para a rua, apenas para divertir os primeiros da fila, mas para fazer o que a gente tem feito: espetáculos com quinhentas, seiscentas apresentações. Espetáculos onde o público todo senta no meio da rua e consome um espetáculo com texto em uma hora. Então a gente acha que nós estamos bem encaminhados, nada resolvidos, mas encaminhados. Em quinze anos nós não acreditávamos em fazer teatro na rua com 
texto - foi quando a gente fez Romeu e Julieta. Até então a gente fazia um teatro instantâneo, acrobático, pesquisando cenografias, pesquisando formas, e não acreditávamos no homem comum, de que ele pudesse consumir um clássico, por exemplo, na rua.

Descobrimos que trabalhamos com ferramentas que a expressão popular nos dá - que até então tínhamos uma atitude um pouco reacionária a respeito - a gente podia chegar ao ponto onde chegamos. ...porque nos consideramos artistas do povo...

Histórias do teatro brasiliense:

Esquadrão da Vida - 23 anos fazendo palhaçada (Ary Pára-Ráios).

O Esquadrão da Vida entra no seu vigésimo terceiro ano de existência com razoável acúmulo de experiências. Da sua primeira aparição no fim da década de 70, até hoje, guarda o entusiasmo que o levou para uma nova experimentação estética: a dramaturgia do corpo no teatro de rua. Nestes 23 anos o Esquadrão da Vida se encontrou com o povo na rua e se familiarizou com grandes autores e teóricos no trabalho cotidiano.

Os frenéticos 23 anos de estertor do Século XX formataram permanentes reedições do 1984, de George Orwell e trouxeram a contradição como coerência e o apocalipse como regra. O Esquadrão da Vida chega ao Circo XXI aceitando essa bagagem. Suas formas se adaptaram às compulsões de uma leitura dinâmica de atualidades. Seus espetáculos são dinâmicos, alegres, movimentados, acrobáticos. Aceitam e reciclam os dados da informação eletrônica sem sacrifício para as expressões do povo. Suas roupas se adaptam ao avanço da indústria têxtil; sua dramaturgia tornou-se cada vez mais emergente sondando e dando resultado à rua - hoje moradia e ambiente de hordas de seres humanos nos quais a "mensagem" tem que cravar como tatuagem para se assimilada; sua cenografia reciclou e transformou em picadeiro o ambiente cada vez mais hostil e expresso dos calçadões e parques encampados como propriedade exclusiva de uma eternamente emergente classe média terceiro-mundista.

Algo não mudou nos 23 anos do Esquadrão da Vida: seu entusiasmo juvenil, sua cega crença em melhores dias e sua inabalável fé na arte e na utopia na busca de uma justa distribuição dos bens da raça humana. Também o figurino, no íntimo, ainda é o mesmo. O do palhaço. Com sobras e falhas que não lhe permitem se 
encaixar na normalidade de uma sociedade cuja sanidade ainda está para ser provada.

Nestes anos o Esquadrão da Vida procurou e conseguiu atingir algumas metas. Como a de identificar-se com o povo da sua cidade. Não há hoje em Brasília uma quadra que não tenha visto um espetáculo do Esquadrão da Vida. Na rua com Romeu e Julieta, sua ópera-cordel que viajou por diversos estados brasileiros, aqui teve mais de 400 apresentações que esquadrinharam o Plano Piloto de fio a pavio por quase cinco anos. Sua intervenção urbana Guerrilha do bom humor, teve milhares de apresentações mostrando poesia, música, acrobacia e folclore brasileiro para crianças, adultos, jovens e velhos em parques, hospitais, escolas, feiras, auditórios e teatros.

Foi assim também o sucesso com a Guerrilha do bom humor para cerca de 50 mil crianças e adolescentes na exposição $O$ Brasil encantado de Monteiro Lobato, de Elifas Andreato, realizada em Brasília no Teatro Nacional em julho de 98.

A conquista de uma linguagem dramática própria deu aos componentes do Esquadrão da Vida uma empatia hoje reconhecida pelo grande público, por artistas e principalmente pelas crianças. Suas oficinas de iniciação e aperfeiçoamento teatral: "Instituto palhaço", "Teatro da palavra ao corpo", "Para aprender a voar e corpo /coração" são parte do trabalho que desenvolvem com o grande público pelos lugares por onde passa.

O bicho homem e outros bichos contou com o oito temporadas anuais, percorrendo o caminho aberto por Na rua com Romeu e Julieta, com mais de 300 apresentações.

O Esquadrão da Vida continua agora com seu trabalho e alegria, levando sua Folia Real para as ruas. E com o mesmo entusiasmo que começou, 23 anos atrás.

Outro grande artista da cidade é Chico Simões, um artista completo e conhecedor das nossas origens.

Vamos agora as palavras e sentimentos de Chico Simões.

Como nasce o Mamulengo em uma Brasília sempre a inaugurar-se. (Chico Simões). Chico Simões é ator, autor, diretor e mamulengueiro. Foi fundador e integrante do Grupo retalhos e integra e dirige o Mamulengo Presepada. 
A história do mamulengo em Brasília começa a dois mil quilômetros daqui, estamos no sertão do Ceará, "no ano da graça de nosso senhor Jesus Cristo de 1983.

E foi ainda em 1983 que parti para o nordeste a convite de Carlinhos Babau do Carroça de Mamulengos com o objetivo de conviver e aprender com mestres da cultura popular brasileira os mistérios desses ofícios ancestrais ligados ao teatro popular. Entre idas e vindas foram dois anos de intensas convivências que fundaram a base do teatro que faço hoje, voltei para Brasília em 1984, tinha vivido uma experiência de verdadeira iniciação pois de cada mestre que conheci sempre aprendi algo mais sobre o teatro e sobre a vida e posso afirmar a vocês; cultura popular, como bem observou Glauber Rocha, não é o que se chama tecnicamente de folclore, mas uma herança cultural que recebemos e temos o dever de dignificá-la acrescentando nossa própria visão de mundo, sem destruí-la e finalmente devemos também transmitir o legado recebido, desde que apareçam jovens, como vocês, interessados e curiosos com este fenômeno inerente ao ser humano que permite a um ator trans-figurar-se através da ação em um anjo que na porta do céu vaticina: "a entrada por aqui é proibida aos que não trazem o justo passaporte". Bem vindos!

"O ambiente em que foi formado o teatro de bonecos "Mamulengo Presepada" é delirante. Milhares de romeiros se deslocam rumo à "terra santa" de Juazeiro do Norte, os moradores seguem à risca, a recomendação do padre Cícero Romão (1844-1934): "em cada casa uma oficina, em cada oficina um santuário." Os penitentes atropelam-se em peregrinação ao horto onde repousam os restos mortais do santo padre. Movidos pela fé, trazem ex-votos. São milhares de peças esculpidas, cabeças, troncos e membros, muletas, fotografias de enfermos, mechas de cabelo, velas e fitas. Flores de plástico e verdadeiras se confundem, enchem igrejas e salões sempre abarrotados de penitentes que deixam seus ex-votos e sobem o horto para pagar a promessa. Crianças maltrapilhas contam em versos, por poucos tostões, a incrível história dos milagres realizados pelo "Padrinho" Padre Cícero Romão. Fotógrafo "lambe-lambe" misturam-se aos Polaroids para oferecer instantaneamente uma imagem do romeiro ao lado do "santo". Violeiros repentistas improvisam pelejas de cantoria, enquanto vendem folhetos de literatura de cordel. São histórias de amor e guerra, relatos "transhistóricos", uma realidade e ficção que extrapolam o "realismo mágico" e fantástico, da literatura latino-americana. Cegos cantam seus sofrimentos, suplicando esmolas e fazendo soar rabecas, violas e 
sanfonas, afinadas por dissonâncias autênticas que criam uma atmosfera de eternidade extraterritorial, onde Jesus Cristo, apóstolos, guerreiros medievais, princesas e castelos são contemporâneos de Padre Cícero e outros beatos, que ainda hoje vivem pelo sertão, fazem milagres e alimentam de fé um povo que só por ela vive.

Aqui se arma a barrada de brincar o Cassimiro Côco. É o topos em que a terra se move sob os pés e fica claro a sentença de Glauber Rocha: "Cultura popular não é o que se chama tecnicamente de folclore. "Em Juazeiro do Norte, o letrado conhecimento vigente sobre a cultura popular brasileira revela-se um "pré-conceito", um "pré-juízo".

No bairro do Romeirão, a "Carroça de Mamulengos", do Mestre Carlinhos Babau, prepara-se para mais uma brincadeira. A tolda é de madeira e revestida por um tecido florido. Não há luz elétrica, acendem-se vários lampiões e lentamente a multidão aproxima-se. A arte do mamulengo não divide o público por faixa etária. Pedro Oliveira, o cego, afina a velha rabeca. É o último aviso, a função vai começar.

Os bonecos aparecem na boca de cena, são de vara ou luva, fazem estrepulias, dão cambalhotas, rebolam e cantam loas provocadas as primeiras gargalhadas, devolvendo ao mamulengueiro a satisfação do brincar. Dependendo do grau de "iluminação" de quem brinca e de quem assiste, uma brincadeira nessas condições pode durar entre uma e sete horas.

Os gigantões de Olinda:

Saltando, ou pulando literalmente para o carnaval de Olinda, topa-se com dezenas de bonecos gigantes que passeiam pelas ruas, roubando-lhes o fluxo intenso da festa. A estética dos "gigantões" brasileiros penetra em outras manifestações de rua e alarga o acervo das experiências cênicas dando-lhes um novo alento. Outro personagem, fácil de se ver nas feiras e praças movimentadas, é o boneco ventríloquo, contestador e malcriado muito usado por vendedores ambulantes de ervas medicinais, charlatães de grande credibilidade popular, que, certamente, sem o boneco falante, jamais prosperariam em seus negócios.

Tudo isto compõe a complexidade do universo do teatro de bonecos que se faz hoje em Brasília, em geral por artistas que foram buscar na cultura popular "inspiração" e acabaram encontrando outra maneira de ver e viver a arte e a vida. Mas ainda é possível encontrar também artistas populares que para cá migraram e lutam para sobreviver, como uns "menestréis" anacrônicos, numa constante 
incerteza itinerante. É dessa instabilidade, de uma "opção" por falta de opção, que o mamulengo também mantém-se vivo. Por funcionar, como divertimento sempre vigoroso, cujas regras estão fora do circuito "vital" dos "meios culturais competentes", pois a norma surge de uma lógica da necessidade que condensa o brincante, o boneco e o público.

Mantendo a tradição:

Ultimamente, vários brincantes - pessoas que saem do nordeste e brincam com sua arte nas ruas e feiras, na cidade, (canto, dança, teatro de rua, repente) a exemplo de Antônio Nóbrega) - aqui em Brasília, vem mantendo acesa a chama do mamulengo, conscientes de que, preservar uma tradição não é, simplesmente, copiar o que já foi feito ou fazer "tudo que o mestre mandar". Entre outros mistérios, é impregnar-se, por convivência, da fisionomia e do espírito de uma herança vital, como prescreve Hermilo Borba Filho, desprezando as formas mumificadas que não comunicam sentimentos e visões de um mundo sempre personalíssimo. Enriquecer o patrimônio herdado é dignificar a herança, e permitir que a tradição desfrute e seja desfrutada pelo que provoca de atual em seus espectadores, desligando-se, portanto, do vínculo nostálgico e passadista tão cultivado pelo folclorismo. E era uma vez... "águias de ônix pairando sob o céu."

E concluindo a trajetória do teatro popular brasiliense, vamos as palavras e considerações do Ricardo Gutti:

Ricardo Gutti é: diretor e fundador da Cortejo e Cia de Teatro, Brincante e Mamulengueiro - Ator graduado pela Faculdade Brasileira de Teatro, que também já foi professor - atualmente é professor na UnB.

$\mathrm{Na}$ busca de uma linguagem cênica que refletisse nossa identidade brasileira e, mais do que isso, brasiliense, começamos a realizar parcerias com outros grupos culturais da cidade, participando ativamente do que viria a se transformar no Movimento de Teatro de Grupo e posteriormente na Cooperativa Brasiliense de Teatro. Da nossa primeira parceria, com o Centro de Tradições Populares de Sobradinho (Bumba-meu-boi do Seu Teodoro), brotou o que seria a vertente estética mais importante para o grupo hoje, a pesquisa da cultura popular brasileira.

$\mathrm{Na}$ cidade, hoje, encontramos, não só no teatro mas em diversas áreas, um grande grupo de pessoas com interesse cada vez maior pela cultura popular brasileira. A enorme riqueza e variedade de músicas e de danças presentes nessas 
manifestações, além de encantar, curar e nos conectar com deuses, guarda a principal força de nossa identidade cultural.

O enfoque maior que destaco na denominação de "popular" é o que se opõe às culturas de massa, onde imperam determinados valores claramente nocivos à criatividade e à existência dessas manifestações. Nesse momento de globalização geral, a diversidade cultural aparece como foco de resistência principal contra os valores e produtos que nos são bombardeados diariamente.

A diferença entre o Catira e o Fandango, entre as brincadeiras de Bumbameu-boi do Maranhão, do Amazonas, de Pernambuco ou de Santa que a aplicação de uma idéia. Essa construção dramatúrgica coletiva, cada vez mais, tem dado subsídios ao desenvolvimento individual dos participantes do grupo, refletindo-se nas encenações de solos de dramaturgia própria.

Um aspecto interessante a observar na dramaturgia popular é a continuidade do tema. A busca do novo para o brincante está no improviso do verso e não na história contada. O eixo da dramaturgia se mantém constante. Encontramos, nas manifestações populares com tradição bastante antiga, um formato totalmente delineado, o que talvez realize o salto estético que leva o espetáculo ao rito.

$\mathrm{Na}$ pesquisa sobre o palhaço que realizo desde 1987, o "clown" vem sendo substituído pelo "Mateus". Obviamente miscigenado, o Mateus joga como os mimos que fizeram parte do teatro romano, como um servo da commedia dell"arte, personagem de caráter fixo, que se mantém, respeitando as transformações sociais, como eixo da dramaturgia popular.

O motor dessa dramaturgia é o povo que, na máscara do empregado, reflete seus conflitos e suas necessidades. Esse anti-herói, através de seus medos e tombos, mandingas e artimanhas, é figura forte e ridícula, que conduz com maestria festas religiosas e profanas, mantendo a alma do espectador aquecida na improvisação de seu verso.

O teatro de bonecos popular brasileiro (Mamulengo, Cassimiro Côco, João Redondo) nos apresenta, de forma cômica e crítica, outras máscaras sociais, como a do policial, da mulher sensual, do padre, etc. e tem em Brasília uma legião de seguidores. Arrisco-me a dizer que o DF é o segundo estado brasileiro em número de brincantes desse folguedo.

Dentro da rotina de treinamento do ator, o contato com a cultura popular introduziu ainda a prática diária da música, da dança e do improviso, possibilitando 
ao ator um maior desenvolvimento pessoal e um novo sentido da prática cotidiana. Dançando ou batucando na igualdade circular d roda, integrando o eu e o outro, criando interações e interdependências, espelhamos a dinâmica da vida, tentando entendê-la e transformá-la em teatro.

Aprendo sobre o sentido e a importância do trabalho em grupo quando vejo Mestre Teodoro do Centro de Tradições Populares de Sobradinho (CPT) trazendo pessoas de sua comunidade do Maranhão, que estão em geral vivendo em condições precárias.

Assim, estes três depoimentos, demonstram a importância do teatro popular,d a valorização dos artistas cômicos populares, e da diversidade de estética e pensamentos, para o desenvolvimento turístico, artístico e cultural de nossa cidade. Mas minha motivação para a elaboração desta dissertação, foi descobrir como que personagens tão marcantes na literatura agiam. 


\section{CONSIDERAÇÕES FINAIS}

Observei que o grande problema era:

Nas sociedades pós-modernas existe espaço para estes profissionais. É viável se utilizar destes profissionais para aumentar o fluxo turístico em localidades de entretenimento e lazer?

Demonstrando que as práticas de lazer e recreação e cultura popular cômica, são fenômenos sociais que evoluíram ao longo do tempo e encontram-se arraigadas em vários setores de nossa sociedade, um destes fatores apresenta uma importância social e econômica, fundamentos para as sociedades pós-modernas: o turismo, o lazer, a arte e a recreação estão intimamente relacionados, e desta relação surge então, mais uma área para a atuação do animador cultural.

Aos problemas apresentados indica-se os seguintes pressupostos:

Estes personagens tem espaço na cultura pós-moderna, e a importância para o desenvolvimento da cultura, do lazer e do entretenimento faz com que a atividade turística, o lazer e a arte (teatro) podem possibilitar ao indivíduo liberdade, bem estar, integração, desenvolvimento cultural, comunicação, recuperação física e mental, que em geral superam as possibilidades da vida cotidiana. Por todas estas sensações, e também pela expectativa gerada por uma viagem, e que o turista necessita de profissionais capacitados, especializados e conscientes de seu papel.

Quanto à animação e a recreação, surge na atualidade como forma de fazer propiciando formas de experiências, na qual o indivíduo participa, por escolha devido ao prazer e a satisfação pessoal que obtém diretamente dela.

No adulto a recreação e a animação tem uma função recreadora, pois o indivíduo pratica pelas suas necessidades sociais, espirituais e físicas.

"É através da recreação que o adolescente dirige seus impulsos para a atividade e associação coletiva" (Negrine 2001, p. 43).

A metodologia do trabalho será apresentada em forma de pesquisa bibliográfica, pesquisa de campo, com algumas entrevistas à artistas locais que trabalham com teatro popular, mamulengo e com pessoas que trabalham com personagens cômicos (bufões, palhaços e clowns

Esta verificação foi feita por meio de pesquisa bibliográfica e pesquisa de campo - As análises tiveram caráter tanto qualitativo quanto quantitativo, 
possibilitando reflexões multidisciplinares em torno das argumentações iniciais sobre o teatro cômico popular, o riso popular, as personagens cômicas e o mercado de trabalho de tais profissionais nas sociedades pós-modernas e também sobre o ócio criativo (de Masi) (Dumazemer); A sustentabilidade da prática do turismo e do lazer voltado para a animação e a recreação no DF. Os estudos levantados na pesquisa bibliográfica, fundamentaram e explicaram os aspectos sociais, econômicos, históricos, antropológicos, turísticos e artísticos que envolvem as questões levantadas. O referencial teórico levantado possibilitou também a seleção dos conceitos que funcionarão como ferramentas básicas para as análises aqui propostas.

Assim sendo, neste trabalho, o trajeto, o quadro teórico de apoio contempla desde as concepções de autores que falam sobre a arte e o teatro, autores tradicionais (Shakespeare, Mòliere, Cervantes, Rabelais, Bakhtin, Staneslauski, etc.); como também inclui autores contemporâneos como Domenico de Mari, Joffre Rumazedier e outros. No que se refere à pesquisa de campo, a forma utilizada para a coleta de dados foram as entrevistas com as pessoas citadas. 


\section{BIBLIOGRAFIA}

BACAL, Salah. Lazer e o universo dos políticos. São Paulo: Aleph, 2003.

BARBA, Eugênio. A arte secreta do ator.

BEZERRA, Gilvan de Brito. Técnicas de criatividade para a formação de novos atores. Brasília, Df, 1989.

DRAMANTE, A. Estamos vivendo uma civilização do lazer? . Lazer não é brincadeira inútil. Momentos Técnicos, SESI.

CAILLOIS, Roger. Os jogos e os homens. Lisboa, Cotovia, 1980.

CAMARGO, Luiz O. de L. O que é lazer. São Paulo, Brasiliense, 1986.

Primeiros Passos, p. 172, 2003.

O que é lazer. São Paulo, Brasiliense, $3^{\mathrm{a}}$ ed., Coleção

DUBECH, Lucien. Historie générale ilustrée du théâtre. Vol. I, Livraria Francesa, Paris.

1994.

A revolução cultural do tempo livre. São Paulo, Studio Nobel,

DUMAZEDIER, Joffe. Lazer e cultura popular. São Paulo: Perspectiva , 1973.

FERRACINI, Renato. A arte de não interpretar como poesia corpórea do ator. UNICAMP, Campinas, 1998.

FL, Dario. Manual mínimo do ator. Ed. Senac, S.P., 1998.

LEROI, Gourhan, André. O gesto e a palavra. 2 vol. Lisboa ed. 70, 1964, 1963.

MARCELLINO, Nelson Carvalho (ORG.). Lazer: Formação e ativação profissional. Campinas: Papirus, 182 p - coleção Fazer/Lazer.

Campinas: Papirus, coleção Fazer/Lazer, $4^{\mathrm{a}}$ ed., 2003.

(ORG.). Lazer e Empresa: múltiplos olhares.

MARCELLINO, Nelson Carvalho. Pedagogia da animação. Campinas: Papirus (1990).

MIAN, Bobson. Monitor de Recreação: formação profissional. São Paulo, 2003.

MIRANDA, Regina. O movimento expressivo.

NEGRINE, Airton. Recreação na hotelaria: o pensar e o fazer lúdico. Coleção Hotelaria, p. 128, Caxias do Sul: Educs, 2001. 
NICOLL, Allardyce. História Del Teatro Mundial. Desde ensaio a Anoulh. Tradução. Jaun Martin Ruiz Merner, 1964.

ROBATO, Lia. A linguagem do indizível.

RUGGERO, Jacobbi. Teatro da Léri a Domani. La Nuova Itália, 1972.

VIANNA, Klauss. A dança.

WAICHMAN, Pablo. Tempo, arte e recreação: um desafio pedagógico. Tradução Jorge Peres Gallardo. Campinas, São Paulo: Papirus, 1997. 
ANEXOS 


\section{A RECREAÇÃO E A ANIMAÇÃO TEATRAL: CONCEITOS E MERCADO DE TRABALHO}

\section{Principais conceitos pertinentes à recreação e a animação}

\section{Entretenimento:}

Atividade para se divertir e distrair. Diversão como distração ou recreação. Ocupação do tempo, mantendo pessoas em determinado local, utilizando a diversão e a recreação de forma paga.

Satisfação = Marketing.

Preenchimento = Ocupação do próprio tempo.

Gestão do Entretenimento - Direção de negócios, bens ou serviços de atividades programadas para ocupar o tempo de pessoas por meio de diversão/ recreação.

Distração, passatempo. Toda forma de prazer pago.

\section{Criatividade:}

Enfrentar o desconhecido, propondo soluções inovadoras.

Estímulos à criatividade - ambiente físico, comunicação, desafios (tarefas que estimulam o potencial criador), estrutura organizacional, liberdade à autonomia, participação, recursos tecnológicos/ materiais, salários, treinamento, barreiras à criatividade, ambiente físico (inadequado), falta de disciplina, orientação inadequada, impossibilidades de desenvolvimento de idéias novas.

"O cliente não compra produto e serviço, mas sim os benefícios proporcionados por eles".

Busca da Totalidade Interna.

\section{Cultura:}

Conjunto de crenças, valores e técnicas criadas e transmitidas pelo ser humano, estando sujeito a mudanças históricas.

\section{Marketing:}

Estratégias para lançar e manter a imagem de um produto junto ao consumidor. 


\section{Dramatização:}

Adaptação de um texto (épico ou poético) para um texto dramático ou para um material destinado ao palco.

\section{Teatralização:}

Interpretar cenicamente utilizando-se de cenas e pessoas que atuam (atores) para construir uma situação. O elemento visual da cena e a colocação em situações, são marcas da teatralização.

\section{Jogo e Festa:}

Atividades humanas que realizam o lúdico (homo ludens) e a essência do divertimento (prazer/ agradável/ alegria), elimina a vida cotidiana, combina as regras estabelecidas com a liberdade.

\section{Lúdico:}

Tudo aquilo que leva uma pessoa a apenas divertir-se, entreter-se, alegrarse. Equilíbrio entre o mundo interior $X$ exterior. $O$ jogo, a emoção e o lúdico estão no cotidiano das pessoas.

\section{As atividades do lazer e entretenimento:}

Pertencem ao lúdico e as emoções através de profissionais da educação física e das artes, pensadores do livre, corpo, das expressões faciais, da observação do outro, diversão (recreação), atividades no tempo livre.

\section{Animação:}

A animação teatral ou cultural acompanha hoje a simples criação de espetáculos, para preparar em profundidade o terreno de uma recepção mais eficaz dos produtos culturais. Esta noção, surgida na França dentro da corrente da descentralização dramática e da ação cultural, reflete toda a onda da empresa teatral de hoje e de sua função na sociedade: trata-se de criar uma certa animação nos ambientes à margem da cultura ou de promover animações pontuais antes ou depois de um espetáculo para "explorá-lo" em todos os sentidos do termo? Fundamentalmente, a animação entendeu que o teatro não se reduz à análise de um texto e a sua encenação, e sim que nem toda inovação e criação têm a sorte de serem corretamente recebidas num contexto em que o público foi preparado para a arte dramática. É, portanto, por intervenções em escolas ou locais de trabalho que esta política de animação deverá começar. Iniciando os jovens espectadores no jogo dramático ou na leitura do espetáculo, a animação investe num público futuro, sem poder testar imediatamente os resultados de seus esforços. 
As formas de animação variam da discussão após um espetáculo à organização de um teatro e de um público populares (como o TNP de Jean Vilar, nos anos 50 e 60), à apresentação de uma montagem audiovisual em sala de aula ou na televisão, passando por pesquisas num bairro para preparar um espetáculo (teatros do Aquarium nos anos 70 ou do Campagnol), até uma verdadeira colaboração com a população para preparar a encenação. A animação familiariza um público ainda mal informado com o aparelho teatral, dessacraliza este e insere-o no tecido social; ela só tem probabilidade de dar certo se for conduzida no âmbito de uma casa de cultura, de um teatro que tenha um orçamento de exploração satisfatório e com uma equipe de animadores que concebam o teatro como um ato tanto político quando estético. A animação se tornou tão importante para o êxito de um espetáculo que o encenador deve muitas vezes transformar-se em administrador, educador, militante e responsável pelas relações públicas; esta multiplicação de tarefas ingratas e absorventes provoca constantes conflitos com a atividade criadora da gente de teatro e contribui para acentuar ainda mias o fosso entre uma arte popular acessível e uma arte elitista fechada em si mesma. A palavra de ordem de Antoine Vitez de um "teatro elitista para todos" surge como a busca ainda utópica de um equilíbrio entre animação e criação pura.

\section{Animação teatral:}

Prepara e acompanha a criação de espetáculos (teatrais ou performáticos) para maior aceitação e maior eficácia dos produtos culturais e turísticos. É um pensamento descoberto na França. Uma corrente que estudava a descentralização dramática e da ação cultural, mas que já existia de uma outra forma. Desde Aristóteles (A Poética 330aC), criador da teoria Ocidental do teatro, na qual tratava de processos do mundo material, de elementos da tragédia (enredo, caráter, pensamentos, evolução, espetáculo). O teatro passa, então a imitar a ação dos homens, contribui para a sociedade, criando certas animações em ambientes escolares, locais de trabalho, empresas, hotéis, parques temáticos, empreendimentos turísticos, dentre outros.

A animação teatral também auxilia e acompanha as intervenções cênicas e as performances, para juntamente desenvolverem, por estas práticas, em novos espetáculos como fundo educativo e lúdico, e também investe num público futuro sem poder testar imediatamente os resultados de seus esforços. Etapas para um 
bom planejamento da animação: parte física; programação; formação de mão-deobra qualificada.

Relaciona-se e se encaixa, da melhor forma, na temática do lazer, apresentada de forma lúdica, teatral e emocional, que são elementos essenciais. Desenvolve novas perspectivas de mudanças na visão dos empresários, demonstrando que o produto "recreação teatral", trará um retorno não apenas financeiro, como também um retorno emocional.

\section{Performance:}

O que é performance? Uma peça teatral? Dançarinos dançando? Um concerto musical? O que você vê na TV? Circo? Carnaval? Uma entrevista coletiva de um presidente da república? As imagens do papa, do modo como ele é tratado pela mídia ou as constantes repetições do instante em que Lee Harvey Oswald era Baleiro? E esses eventos têm alguma coisa a ver com rituais, ou danças com máscaras como aquelas de Peliatan, em Bali? Performance não é mais um termo fácil de definir; seu conceito e estrutura se expandiram por toda parte. Performance é étnica e intercultural, história e atemporal, estética e ritual sociológica e política. Performance é um modo de comportamento, um tipo de abordagem à experiência humana; Performance é um exercício lúdico, esporte, estética, entretenimento popular, teatro experimental e muito mais, podendo ser: históricas; econômicas; ideológicas; comunicação de valores (religiosas/sociais).

\section{Animação e Recreação (Atividade lúdical Atividade recreativa):}

Recreação - forma lúdica de recuperar as formas para o trabalho;

Divertimento e lazer alvo escolhido livremente;

Atividade de lazer conduzida por Recreador ou Recreólogo. Fato, momento ou circunstância que os indivíduos, de forma espontânea e deliberadamente, através do qual ele se satisfaz (sacia) seus anseios voltados ao seu lazer, satisfação, prazer, bem-estar.

Recrear - Criar de novo. Sinônimo de entretenimento, atividades que produzem prazer (fundo hedonístico) educação no tempo livre, utilizando-se de jogos, atividades recreativas e técnicas expressivas.

A conceituação da recreação é tarefa das mais difíceis. Cada ator tem sua posição e ressalta alguns princípios. Podemos identificar um ponto comum à recreação como ato de criar de novo, recriar, progredir, proceder a um ato criador. 
Recreação é definida como divertimento; prazer; coisas, que recriam, lugar onde alguém se recria. A recreação deve proporcionar prazer, satisfação e bemestar.

Recreação significa satisfação e alegria naquilo que faz, retrata uma atividade que é livre e espontânea e na qual o interesse se mantém por si só, sem nenhuma coação interna ou externa de forma obrigatória ou opressão, afora o prazer.

Segundo Cutrera, o objetivo geral da recreação é: criar condições ótimas para o desenvolvimento integral das pessoas, promovendo a participação individual e coletiva em ações que melhorem a qualidade de vida, a preservação da natureza e a afirmação dos valores essenciais da humanidade.

Características básicas da animação e da recreação: Segundo Cavallari, 2001, p. 16, no Livro Trabalhando com Recreação:

- Busca do fato de recrear = verbo recrear (transitivo) Proporcionar recreio a, deleitar, divertir, alegrar, causar prazer, sentir prazer ou satisfação, divertir-se, deleitar-se, brincar, distrair-se, desenfadar-se.

- Não se busca o retorno.

- Deve ser escolhida livremente e com espontaneidade. Não se pode forçar a prática de recreação, apenas sugerir ou motivar. Os profissionais apenas criam circunstâncias próprias para que as pessoas se recriem.

- Leva a pessoa a estados psicológicos positivos, a um caráter humanístico (ligado ao prazer).

- Propicia as pessoas o exercício da criatividade.

A recreação deve ser encarada pelo praticante como um fim em si mesma, sem que se espere benefícios aos resultados específicos. A pessoa que busca sua recreação nunca terá outro objetivo com sua prática que não apenas o fato de se recrear. Há um total descompromisso e uma total criatividade. Não busca qualquer tipo de retorno.

A prática da recreação busca levar o participante a estados psicológicos positivos.

A recreação está sempre ligada ao prazer. A recreação busca o prazer, é necessário tomar cuidado com a prática e determinadas atividades lúdicas que durante seu desenrolar poderão desviar-se e acarretar no praticante sensações indesejadas e negativas. 
Recreação é a forma lúdica de recuperar as forças para o trabalho. Lazer ativo escolhido livremente. Atividade de lazer conduzida por um animador. Satisfação, prazer, bem-estar.

A recreação deve ser escolhida livremente e praticada espontaneamente, segundo os interesses de cada um.

Cada pessoa terá a oportunidade de opção quanto àquilo que pretende fazer em função de sua recreação, e se preferir, ainda optar por não tê-la naquele ou em qualquer outro momento.

Uma pessoa não pode forçar a pratica da recreação. Podemos apenas sugerir ou motivar. Ninguém recria ninguém. Os profissionais da recreação apenas criam circunstâncias propícias para que cada pessoa se recrie.

A recreação deve ser de natureza à proporcionar a pessoa o exercício da criatividade. Na medida em que se ofereça estimulação, essa criatividade deve ser plenamente desenvolvida.

O momento da prática de recreação é propício ao desenvolvimento da criatividade, pois o acordo com as características anteriores, pois não existem cobrança. É o momento de ser criativo, pois não há nada a perder, nem mesmo tempo, porque é lúdico passar o tempo não importando como. A importância da criatividade para a pessoa é enorme, pois engrandece. A personalidade e prepara para uma condição melhor de vida. O trabalho será muito melhor e apresentará resultados muito mais satisfatórios se desenvolvido desde a infância.

Nas características de organização da sociedade nos níveis econômicos, sociais, políticos e culturais em geral, a recreação de cada grupo é escolhida de acordo com os interesses comum dos participantes.

As atividades lúdicas ativas de recreação e animação, tem sempre um fator diferenciado, uma vez que pressupõem relações interpessoais que provocam resultados significativos de caráter lúdico, pois, produz reações e emoções para o desenvolvimento humano.

Os serviços de recreação e de animação englobam mais uma alternativa de lazer na hotelaria, nos espaços de lazer e entretenimento e nos parques temáticos, uma vez que oferecem atividades pensadas e planejadas como os demais serviços deste ramo (turístico). 
O sucesso empresarial, nos tempos atuais está diretamente ligado e relacionado à qualidade dos serviços que oferece, associado à alternativa que se coloca à disposição dos usuários.

Os objetivos do serviço de recreação e animação, é ao oferecer em determinados espaços de lazer, em hotéis, parques temáticos, elementos de liberdade, lúdico e prazer levando em consideração o espaço físico, as demandas diferenciadas, que permitem o desenvolvimento de atividades lúdicas e recreativas e necessita haver no mínimo uma pessoa, recreador ou recreadora. Isto é, aquele que vai exercer a função de facilitador para que o serviço oferecido sirva inclusive de marketing da empresa.

Este profissional - o recreador - que coordena este tipo de serviço, deve ser especializado e decidir seu trabalho e área de atuação juntamente com a direção dos espaços, e tem como principal objetivo: informar aos hóspedes as alternativas de lazer e recreação que os espaços de lazer e entretenimento, hotéis e parques temáticos oferecem. Buscar a participação livre ou espontânea dos hóspedes nas atividades oferecidas, ampliar e facilitar a comunicação entre as pessoas, criar um clima lúdico, permitir a avaliação permanente aos serviços oferecidos, e serve de elo entre o hóspede (turista) e a gerência do hotel.

A recreação e a animação na rede hoteleira, parques temáticos e nos espaços de lazer e entretenimento no DF:

Os serviços de recreação e animação englobam mais de uma alternativa de lazer e entretenimento que a rede hoteleira, os parques temáticos e outros espaços podem oferecer a seus usuários. Os serviços de recreação e animação nestes empreendimentos devem ser pensados e planejados como os demais serviços que integram o ramo destas atividades.

O sucesso empresarial nos tempos atuais está diretamente relacionado à qualidade dos serviços que oferece, associada às alternativas que se coloca à disposição do usuário. Este aspecto constitui-se na premissa básica que deve nortear o pensamento do empresário a investir neste tipo de empreendimento.

Alguns empresários do ramo nem sempre tem a dimensão do que determina. A opção dos usuários, por um hotel em detrimento do outro. Com certeza muitas são as variáveis que determinam seu comportamento, entretanto, é fundamental que se pense no perfil de tais usuários. 
Deve-se chamar a atenção para dois aspectos fundamentais. Diversificação e qualidade do que é oferecido como atividades de lazer e recreação, em hotéis, parques temáticos, casas de espetáculos, parques de diversão - ao falar em diversificação, quer se referir não apenas as questões relacionadas ao trivial desse tipo de serviços, ou seja, aposentos e alimentação. Esta última, sempre relacionada ao café da manhã.

A qualidade se expressa com significados mais relevantes nas relações interpessoais. Por um lado traduz-se pela competência das pessoas que atuam em cada setor ao cumprimento de suas tarefas, por outro, pelo nível das relações existentes entre funcionários e usuários.

Os animadores de espaços destinados ao lazer e entretenimento devem ter claro que o planejamento, o funcionamento e a oferta de serviços, ao nível das relações interpessoais devem ser pensados para beneficiar os usuários. A sintonia da administração com os diferentes setores e a articulação que pode ser incompleta, dentro de um determinado sistema, fazem parte do somatório determinante da qualidade de serviços oferecidos.

O perfil dos usuários que buscam o lazer nos hotéis e espaços para a diversão nos finais de semana e nos feriados, com certeza não tem o mesmo perfil daquele que ocupa tais espaços durante a semana. São usuários que buscam a diversão, o entretenimento e o ócio criativo, portanto o objetivo é passar dias ou horas prazerosas. Ainda mais porque muitos destes usuários se fazem acompanhar de filhos, geralmente crianças e adolescentes.

A aspecto sócio-econômico dos usuários merece reflexão por parte dos empresários do ramo. Este aspecto, juntamente com o perfil do usuário são aspectos suficientes para justificar a importância da implementação de um serviço de animação ou recreação em espaços de lazer e entretenimento.

Serviços desta qualidade, quando bem planejados e executados por profissionais qualificados e capacitados, poderá se constituir em traço diferencial. Tudo isso justifica em pensar projetos desta natureza uma vez que este ramo da animação e recreação estão cada vez mais diretamente relacionados com o turismo.

A ausência de recreação e animação nos hotéis parques temáticos, ou espaços de entretenimento e lazer, de acordo com os relatos dos gerentes e responsáveis por tais atividades fica a desejar na ocupação, pois, a falta de atrativos nas atividades de lazer e os altos preços praticados na hotelaria na capital, e a falha 
de parcerias com empresas de serviços de animação e recreação, não facilitam em nada.

Os serviços de recreação e animação em espaços de lazer e entretenimento, parques temáticos, hotéis tem a função de ir ao encontro das necessidades e dos anseios do homem moderno, procurando satisfazê-lo, é fundamental que o setor de lazer tenha uma programação flexível e acessível aos diferentes grupos e faixas etárias implantado progressivamente.

\section{Animação sócio-cultural:}

Técnica de diversão e entretenimento usada em festas, auditórios e excursões. Motivar um grupo através de atividades lúdicas.

A animação sócio-cultural tem como objetivos:

- mobilizar as consciências;

- dar sentido as nossas vidas;

- justificação para nossa existência;

- mudança de comportamento.

Sendo assim, animação pós-moderna é:

"Este novo conceito procura traduzir, acima de tudo, uma nova concepção da ação a realizar com objetivo de permitir a afirmação do indivíduo perante ao mundo que rodeia, única forma de promoção pessoal e coletiva... contudo, será sempre um tipo de ação que terá a respeitar as características essenciais das atividades de tempo livre: adesão livre e espontânea do indivíduo, liberdade de escolha do comportamento a adotar, a respeito de suas características e aceitação dos seus pontos de vista, tudo isso na perspectiva de uma real participação e responsabilização livremente aceita e profundamente assumida."

Ação, espontânea e/ou comprovada, que permitirá ao indivíduo assumir o seu próprio desenvolvimento, o que pressupõe uma profunda tomada de consciência, por parte do animador, do significado da cultura e das necessidades do cidadão (turista) e do grupo que atua.

Animação cultural, juntamente com a animação esportiva é fundamental para um aumento de permanência do turista na localidade visitada. É o conjunto de atividades que visa integrar os turistas com as comunidades locais e suas manifestações culturais (destas localidades), desenvolvendo a vivência (emoções lúdicas e a memória emotiva) dos turistas, fazendo com que este turista se torne um divulgador espontâneo da sociedade e da localidade. Dividem-se em: 
1 - informação = apresentação, palestras, seminários, cursos, festivais;

2 - Criatividade = oficinas, turistas artesanais, teatro, culinária folclórica;

3 - Formação = Cursos sobre a cultura local.

Animação cultural contribui para a formação de níveis culturais conformistas através da prática de atividades de lazer.Tem como principal tarefa, elevar o grau de informação para que as pessoas (turistas) possam obter maior participação social, no lazer, se referindo a seu duplo aspecto educativo.

\section{Animação turística:}

As metas básicas da animação (animação teatral/animação recreativa), visam atender cada segmento da demanda turística. As modalidades turísticas, seus perfis motivacionais, em prol do turista ou viajante, ou ainda, pessoas que estão em seu tempo livre estabelecendo uma distinção entre: Produto animação e animação do produto.

É na verdade um complexo turístico ou um complexo de entretenimento e demanda de: muito tempo e muitas pessoas; alto custo; planejamento arquitetônico e urbanístico; animação integral; o animador uma vez integrado ao empreendimento, deve demonstrar-se altamente capacitado e habituado para exercer suas funções. Ex.: Centros de Feiras, Clubes de Turismo, Colônias de Férias, Parques Temáticos, Turismo Social e outros.

Todas as demais modalidades do turismo usufruem a ação da animação: Meios de hospedagem; meios de transporte; agentes do turismo receptivo (guias

\footnotetext{
Características básicas da animação teatral, recreação e principais idéias do Marketing turístico:

- Busca do fato de recrear = verbo crear;

- Não se busca retorno = tudo é conseqüência

- Deve ser escolhido livremente: com espontaneidade;

- Não se pode forçar a prática da recreação, apenas sugerir ou motivar;

- Os profissionais apenas criam circunstâncias motivadoras para que as pessoas se recriem.

- Desenvolve novas oportunidades nas pessoas, bem como estados psicológicos positivos, de caráter hedonístico (ligado ao prazer) pois a recreação busca também o prazer;
}

- Propicia a busca da criatividade humana; 
- Sensibiliza os cinco sentidos (audição, tato, paladar, olfato, visão) e os sete pecados capitais (avareza, gula, inveja, luxúria, vaidade, preguiça, ira);

- Cria situações de aprendizagem e encantamento emocional (cognitiva afetiva- psicomotora - jogos - belo - prazer);

- Folclore e cultura brasileira vista pelos estrangeiros como o país paraíso (animais falantes, mulheres semi-nuas, frutas, músicas, exótico);

- A animação como mobilizador de consciências, dando sentido e justificando a nossa excelência em um processo que visa mudanças de comportamento;

- Fortalecimento da infra-estrutura profissional/ excelência dos produtos serviços.

\section{Emoção:}

A palavra vem do francês émotion, que por sua vez é formada pelo modelo motion, do latim mötiö - önis (etimológico nova fronteira) e significa "ato de mover (Dicionário Aurélio)". Como vemos, o próprio termo indica algo que está em torção, em mutação, e é portanto mutável (condição para que seja emoção). Podemos simplesmente senti-las. Se a emoção é algo que está em movimento dentro de nós, não podemos conduzi-las segundo nossa vontade, mas simplesmente senti-las, deixá-las fluir, circular, movimentarem-se. "As emoções são independentes da vontade". Grotwski, 1988.

A palavra emoção no terceiro verbete do dicionário Aurélio diz que "é uma reação intensa e breve do organismo a um lance inesperado a qual se acompanha de um estado afetivo de conotação penosa ou agradável. Deixar vir à tona qualquer emoção, significa mostrar-se descobrir-se ou ainda, conhecer-se.

O mito das emoções da "memória emotiva" enquanto método para o próprio Stanislavski, é a busca através das emoções do ator ou do comediante que este ator ou comediante empregue vida emotiva. Ao seu papel dentro das circunstâncias oferecidas pelo espetáculo a fim de criar corpo e mente relacionados entre si - para o ator sentir emoção é fazer com que o público (turista) também sinta. A emoção faz com que apareça a grande diferença dos bons e dos maus comediantes.

O bom comediante sabe que sua arte, brota da criação do seu íntimo e sempre estará presente em apresentações, levando ao público a alegria de estar compartilhando o verdadeiro sentido da arte de interpretar; enquanto o mau 
comediante cria em torno de si, uma atmosfera falsa e um realismo absurdo, incapazes de provocar qualquer emoção no público e em si mesmo.

Para Bérgson (filósofo francês que afastando-se do dogma positivista, a religião trás a ilusão da transcendência, acreditava no método da intuição como o caminho mais elevado para o conhecimento) criação antes de tudo significa emoção. Bérgson, assim como Stanislavski, colocava a emoção à frente de qualquer criação.

Bolevaski, celebrado diretor de teatro, afirma que a partir da memória emotiva o ator ou o comediante é capaz de tornar verdadeira a emoção proposta pela personagem em determinada circunstância da apresentação popular.

O ser humano se emociona com histórias de seres humanos, através de motivadores como: Ações físicas (corporais, gestuais); Ações sonoras (sons, ruídos, gritos); Ações faciais (sobrancelhas/ lábios/ olhos).

Tipos de emoções:

Emoções eruditas, emoções populares;

Emoção televisiva: narração de fatos, fantasia, sonho, velocidade na comunicação, (novelas, comerciais, programas jornalísticos).

Emoção cinematográfica: nostalgia, sonhos quase impossíveis, ficções científicas.

Emoção em frente a uma obra de arte;

Emoção ao ouvir uma música (clássica, ópera);

Emoção teatral (diante de uma peça teatral);

Emoção esportiva;

Emoções diurnas (voltadas para a razão - físicas/ mentais);

Emoções noturnas (voltadas para a sensibilidade corporal - intuição)

Cada animador, ator, comediante ou recreador, possui sua própria capacidade criadora, individual e única: se há verdade, há sinceridade, há emoção. Para um animador cultural popular, ou para um ator acreditar no que está fazendo é como recordar as brincadeiras de criança. Quando uma garotinha brinca com uma boneca, acredita ser sua filha, dando comidinha, penteando os cabelos. Assim como o garoto, que, ao jogar bola, acredita ser jogador de futebol no meio de um campeonato. Quando somos crianças e realizamos determinadas ações físicas que dão realidade à brincadeira, assumimos com verdade o papel que estamos desempenhando. Acreditamos que o cenário é real. 
A criança em seu mundo lúdico, vive a emoção certa, na hora exata, sem nenhuma falha. Consegue demonstrar toda a verdade que o seu papel, dentro da brincadeira, tinha que expressar, sem nenhum medo e senso de ridículo. Também os animadores são capazes de brincar com o que lhe foi apresentado de maneira genuína, sem permitir que o seu mundo real se torne falso.

\section{A Mímesis Corpórea:}

A mímesis corpórea possibilita ao ator a busca de uma organicidade e de uma vida a partir de ações coletadas externamente, através da imitação de ações físicas e vocais de pessoas encontradas no cotidiano. Além das pessoas, ela também permite a imitação física de ações estanques como fotos e quadros, que podem ser, posteriormente ligadas organicamente, transformando-se em matrizes complexas. Cabe ao ator a função de "dar" vida a essa ação imitada, encontrando um equivalente orgânico e pessoal para a ação física/vocal.

Podemos considerar que existem três fases no caminho da Mímesis Corpórea:

1. Observação: trata-se sobretudo de uma observação ativa, ou seja, observação - imitação. O ator observa uma pessoa e tenta em seguida imitar a corporeidade, ou detalhes da corporeidade, com seu próprio corpo. Estabelece-se, conforme o caso, uma dinâmica entre observação-imitação-observação-imitação... que permite ao ator conferir, na medida em que tenta imitar, uma série de detalhes das ações físicas da pessoa observada. Esta dinâmica ocasiona um aperfeiçoamento e uma melhor precisão na imitação.

2. Codificação: uma vez transferidas para o corpo do ator as ações observadas, inicia-se um processo de memorização e codificação destas ações. A memorização não deve, no entanto, ser mecânica, ela deve ser decorrência da busca de um melhor aperfeiçoamento da imitação: a busca de se lembrar de detalhes ainda mais precisos. A memorização está embutida no processo anterior de observação-imitação, no entanto, se considerarmos o processo como um todo, ou seja, observação-imitação-memorização-codificação, teremos que no início, se está mais próximo do modelo observado, e à medida em que se avança no sentido da codificação, se afasta naturalmente do modelo. Neste momento da codificação, busca-se dar um nome para cada ação imitada, mesmo se advindas de um mesmo modelo. O nome serve para o ator identificar rapidamente uma ação, ele não revela propriamente o conteúdo da ação. Por este motivo, é um nome fantasia. 
3. Teatralização: uma vez imitadas, codificadas e memorizadas, as ações passarão por um processo de teatralização. Elas são retiradas do contexto que as originaram, transformando-se, como vimos, em materiais ou objetos de trabalho. Ou seja, uma vez recuperadas, estas ações podem ser trabalhadas. "trabalhar uma ação significa operar pequenas alterações em elementos componentes desta mesma ação. Assim, por exemplo, podemos alterar o tempo ou o ritmo da ação, ou ainda sua espacialidade, ampliar o impulso, dilatar um contra-impulso, ou encontrar o elemento corpóreo de contradição desta ação, amputar partes como um membro, ou introduzir partes como um olhar, ou um contra-impulso, e assim por diante. A teatralização é precisamente o momento no qual operamos a transferência das ações observadas de seu contexto e dimensão natural e originário, para o teatral; é quando elas passam de apresentadas para re-apresentadas. A teatralização é também a dilatação desta ação, ou de partes dela.

A partir desse universo concreto, parte-se para a pesquisa das ligações orgânicas e pessoais entre as ações e o ator, também embasada em elementos concretos anteriormente trabalhados, através dos elementos pré-expressivos. Recorro novamente aos próprios atores para substancializar, ainda mais, essas palavras:

O fantástico da mímesis é que ela me aproximou muito do teatro ao qual estamos habituados, "teatro de personagem" vamos assim chamar, sem contudo fugir de todos os conceitos que eu havia assimilado anteriormente. A mímesis me fez enxergar que em qualquer lugar existe o pretexto para fazer teatro. Se estivermos atentos para as coisas e os seres que nos cercam, teremos sempre ao nosso alcance o motivo, o ponto de partida. A mímesis é uma brincadeira séria. Brincar de ser o outro, de agir como o outro: brincar de ser vários num só. Brincar também de ser fada, de dar vida às coisas estáticas, de dar três dimensões àquelas que não as tem. Um quebra-cabeças para lá de complexo, que depois de montado uma vez não se desfaz jamais e, pelo contrário, ganha vida própria e o direito de se transformar. A mímesis modificou totalmente o meu olhar e fez surgir uma ligação direta entre olhar, coração, músculo, nervo. Me sinto uma escultora esculpindo em meu próprio corpo. Acho a Mímesis muito importante também porque é um trabalho que me conecta com um mundo real, que me põe diante de questões muito concretas da minha pessoa em relação ao meio. (Raquel Scotti Hirson, entrevista, 1997). 


\section{O mercado atual dos animadores, cômicos populares}

\section{Oportunidades e novas tendências dentro da recreação e da animação} cultural:

- Interesses artísticos, intelectuais, físicos, desportivos, manuais, sociais e turísticos;

- Desenvolvimento no campo de domínio do imaginário, trabalhando com as imagens, as emoções, os sentimentos, a busca da beleza e do encantamento;

- Animação em filas, ônibus, aviões, navios (meios de transportes);

- Parques temáticos e locais de entretenimento;

- Animação de grupos (guias turísticos) durante excursões;

- Programação cultural em locais de turismo e lazer;

- Perceptividades lúdicas, emocionais e artísticas em aeroportos, hotéis, museus, galerias de arte, complexos arquitetônicos, supermercados, resorts, etc.;

- Desenvolvimento do teatro em locais diversos (locais globais): escolas, hotéis, acampamentos, festas, clubes, parques aquáticos, empresas, academias esportivas, natureza;

- Desenvolvimento das manifestações culturais, utilizando o teatro de várias formas:

Teatro de bonecos; teatro infantil; teatro temático; teatro empresarial; teatro educativo; teatro juvenil; teatro adulto; carnaval; danças típicas; restaurantes temáticos; grupos folclóricos.

\section{Os profissionais e principais áreas de atuação}

Mercado de trabalho e o perfil do profissional na área de recreação e da animação teatral:

- Recreação em hotéis;

- Organizações públicas e privadas especializadas em gestão do lazer;

- Desenvolvimento de programas nas Secretarias de Turismo, Cultura e Lazer;

- Academias de ginásticas: animação teatral ocupacional;

- Eventos em geral: culturais, artísticos, recreativos.

Perfil do profissional:

- Formação;

- Informação;

- Comportamento e atitude; 
- Atualização - auto-formação permanente;

- Imaginação e intuição;

- Criatividade;

- Cooperativismo;

- Dedicação;

- Inovação;

- Comunicação;

- O animador/recreador: especialista na área do lazer e cultura, executor de atividades de animação/recreação, mobilizador de consciências, das emoções lúdicas e da memória emotiva.

O profissional e os exercícios, atividades e jogos que exploram e desenvolvem no ser humano o imaginário, a partir da vivência pessoal:

- Memória emotiva (afetiva) X Memória muscular;

- Emoções;

- Espaços;

- Pessoas;

- Objetos;

- Composição cênica - construção do corpo dramático e do movimento dramático.

Metodologia

- Exercícios técnicos, dramáticos e cênicos;

- Filmes;

- Vídeos;

- Vivências e práticas envolvendo jogos;

- Jogos dramáticos; lúdicos e sensoriais;

- Atividades de criação individuais e coletivas;

Análise dos temas e conceitos, debates, relatórios, apresentações de experiências, etc. 